\title{
Freie Mitteilungen / Communications libres
}

\section{Aorta und zentrale Gefässerkrankungen Aorte et pathologies vasculaires centrales}

\section{FM1.1}

\section{Long term results of endovascular treatment of traumatic aortic injuries: a 16-years single center} experience

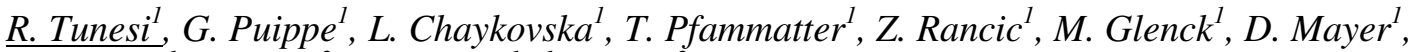 \\ R. Pfiffner ${ }^{1}, F$. Veith ${ }^{2}$, M. Lachat ${ }^{1}\left({ }^{1}\right.$ Zürich, ${ }^{2}$ New York)
}

Objective: Traumatic aortic injury (TAI) due to blunt trauma has a high mortality rate. Endovascular repair of TAI has shown significant short-term benefits compared to open repair. Goal of this study was to evaluate the long term results after thoracic endovascular aortic repair (TEVAR) of TAI.

Methods: Patients who became TEVAR for TAI were prospectively followed-up. Patients were treated following our algorithm for management of acute aortic lesions. Data from the regularly follow-up visits inclusive computed tomography angiograpy (CTA) were collected. Patients were contacted and questioned about problems related to the endograft. Primary outcome were 30 days mortality, stroke, paraplegia and reinterventions. Secondary outcome included secondary procedures and mortality.

Results: Between March 1998 and November 2013, 46 patients (38 males) were treated for TAI in our institution. Median (range) age was 43 (18-85), Injury Severity Score (ISS) 43 (25-59). There were 45 thoracic and 1 abdominal TAI. Left subclavian artery was covered in 20 patients (44\%). Rates of 30 days mortality, stroke, paraplegia and reinterventions were $8.7 \%, 4.3 \%, 8.7 \%$ (2 patients with pseudocoartaction and 2 with traumatic spinal cord lesions) and $10.9 \%$ (2 stentgraft collapse with pseudocoartaction, 2 carotid-axillary bypass and 1 access complication), respectively. 6 patients were lost of follow-up, 2 with no follow-up at all and 4 during the follow-up (after 5, 34, 46 and 74 months). Median (range) follow-up time was 71 (1-184) months for clinical/telephone interview and 37 (1-168) months for CTA. There were 2 secondary procedures (5\%), 1 stentgraft relining 17 months after TEVAR because of pseudoaneurysm formation and 1 carotid-axillary bypass 10 months after TEVAR. 3 patients (5\%) died during the follow-up. Survival was $93 \%$ at 30 days, $89 \%$ at 2 year, $86 \%$ at 5 year and $86 \%$ at 10 year (Kaplan Meyer).

Conclusion: Our data show that TEVAR of TAI is an effective, safe and durable treatment. Device related adverse events and secondary procedures are rare and happen mostly during the first year after TEVAR. This suggests that an extension of the interval of the follow-up after the first year in this younger patient population should be safe. Confirmation of our results in a study with bigger patients' number is suitable.

\section{FM1.2}

In-hospital outcomes after synchronous carotid endarterectomy and coronary artery bypass grafting V.Makaloski ${ }^{1}$, I. Zubak ${ }^{1}$, M. Czerny ${ }^{2}$, J. Schmidli ${ }^{l}\left({ }^{1}\right.$ Bern, ${ }^{2}$ Zürich)

Objective: Synchronous performance of carotid endarterectomy (CEA) and coronary artery bypass grafting $(\mathrm{CABG})$ is controversial due to a potential summation of complication rates. Minimal extracorporeal circulation (MECC) reduces the surgical risks associated with conventional ECC 
significantly. Aim was to evaluate whether synchronous CABG using MECC imposes an additional perioperative risk to CEA compared to isolated CEA.

Methods: A consecutive series of patients (January 2005 to December 2012) undergoing CEA at a single institution was analysed. Perioperative outcomes were compared between patients undergoing synchronous CEA/CABG using the MECC system and patients undergoing isolated CEAs during this time period. Primary outcome measures were in-hospital mortality and stroke.

Results: A total of 367 CEAs was performed during the study period. Some 46 procedures were excluded because they were either combined with off-pump CABG or with cardiac surgery other than CABG. Of the remaining 321 patients, 74 had synchronous CEA/CABG (23\%) using MECC and 247 underwent isolated CEA (77\%).

The proportion of symptomatic carotid disease was significantly different between the groups $(22 \%$ in the synchronous group vs $55.5 \%$ in the isolated CEA group; $\mathrm{p}<0.001$ ). In each group one death and 3 strokes were registered. Interestingly, in both groups 2 strokes were ipsilateral and one was contralateral to the operated site. Statistically there was no difference between the groups regarding mortality $(1.4 \%$ vs $0.4 \% ; \mathrm{p}=0.40)$ and stroke rate $(4.1 \%$ vs $1.2 \% ; \mathrm{p}=0.25)$. Isolated CEA was associated with a shorter hospital stay (mean of 7.5 vs 13.2 days; $\mathrm{p}<0.001$ ).

Conclusion: In-hospital outcomes with regard to mortality and stroke is excellent in both- patients undergoing CEA alone as well as patients undergoing synchronous CEA and CABG using the MECC system. Although synchronous CEA/CABG using the MECC system has a slightly increased stroke rate, it could be considered as combined treatment in particular clinical situations.

\section{FM1.3}

\section{Management of juxtarenal aortic aneurysms in high risk patients: First experiences with the Anaconda F-EVAR}

\section{S. Hofer, G. Heller, P. Knüsel, M. Furrer (Chur)}

Objective: Since the availability of fenestrated stentgrafts (F-EVAR) the management of high risk patients with juxtarenal aneurysms has changed significantly. What is the percentage of such patients finally having successfully excluded their aneurysm by a fenestrated graft? What is the fate of the otherwise treated patients?

Methods: High risk patients for open surgery presenting with an abdominal aortic aneurysm with no or minimal infrarenal neck length (less than $5 \mathrm{~mm}$ ) were prospectively included in the study for an eventual F-EVAR implantation (Anaconda, Vascutek). The decision making process, the time until the eventual operation and the intermediate term outcome (with a follow-up after 3, 9 and 15 months) were/will be analysed in all patients.

Results: Nine high risk patients $(6 \mathrm{~m} / 3 \mathrm{f}$, mean age 80 , range $64-88)$ are included so far. Three patients had a F-EVAR implantation, the mean delay until procedure was $12(8-16)$ weeks, one patient is planned for the procedure. All F-EVAR patients had a successful implantation and an uneventful course so far. Five patients were excluded for a F-EVAR procedure because of anatomical reasons of the perirenal aortic zone. Of these five patients one denied an open procedure and remains under conservative follow-up, one had an open repair with an uneventful course one more is planned for open procedure, one patient had an off-label use of an infrarenal stentgraft with successful implantation and re-intervention because of an endoleak Type II (but not Typ Ia) with a growing aneurysm sac and one patient is planned for off label use of an infrarenal stentgraft.

Conclusion: In our limited initial experience a third of the high risk patients presenting with juxtarenal aneurysms could be treated with the Anaconda fenestrated stentgraft. In patients rejected for a F-EVAR procedure an individual decision making process should evaluate alternative treatment options that might be performed successfully as well. 
FM1.4

Long-term results of parallel grafts used to revascularise the renovisceral vessels: a six-years single center experience in 100 patients with pararenal and/or thoracoabdominal aortic aneurysm

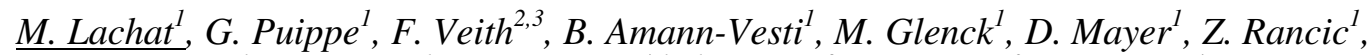
T. Pfammatter ${ }^{1}$, B. Krüger ${ }^{l}$, F. Pecoraro ${ }^{4,1}\left({ }^{1}\right.$ Zürich, $^{2}$ Cleveland, ${ }^{3}$ New York, ${ }^{4}$ Palermo)

Objective: Endovascular treatment of pararenal abdominal aortic aneurysm (PAAA) and/or thoracoabdominal aortic aneurysm (TAAA) is usually performed by fenestrated/branched endovascular aneurysm repair (F/B EVAR). Customization and anatomical feasibility related limitations exclude a significant number of patients from B/F EVAR treatment. To show supportive data with long-term outcomes we report the single-center experience with parallel grafts in 100 patients presenting PAAA and/or TAAA.

Methods: From January 2008 to August 2013 data from 100 consecutive patients with at least one Chimney graft (CG) or Periscope graft (PG) were analysed. Aneurysm included 69 PAAA and 31 TAAA. Seventy-three patients were treated electively and 27 non-electively with symptoms (15) or aortic rupture (12).

All patients underwent to chimney and/or periscope graft $(\mathrm{CPG})$ treatment by a standardized protocol with specific imaging and measuring, endovascular techniques, perioperative management and followup. Short term outcomes included: immediate technical success rate (procedure completed as intended with no evidence of high flow type I or type III EL and/or CPG occlusion), 30-day mortality and morbidity (renal, respiratory, visceral and access complication and infection), ICU and hospital duration, CPGs patency rate and presence of endoleak at 30-day. Late outcomes included: Survival, CPG patency rate, endoleak rate, maximal aneurysm size and reinterventions during follow-up.

Results: Immediate technical success was 99\% and 30-day mortality was 2\%. A total of 224 (mean 2.24 per patient; SD: 0.9) branch arteries were treated with CPGs. Mean follow-up was 20.11 (r: 0-56; SD:14) months; 39 patients were followed $>2$ and $14>3$ years. During follow-up, 10 (4.5\%) CPGs occluded and five patients had persistent type I/III endoleak. Reduction $(>5 \mathrm{~mm})$ in maximal aneurysm diameter occurred [72mm (SD: 23) to 62mm (SD: 23); $\mathrm{P}<.001$ ] in 56 patients. Cumulative survival rate at 24 and 48 months was $82 \%$ and $75 \%$.

Conclusion: PAAA and TAAA repair using CPGs and off-the-shelf devices was versatile, safe and durable in this cohort of patients. Branch occlusions, endoleaks, aneurysm exclusion and patient survival compared favorably to other methods of repair of these complex aneurysms. With the appropriate technical precautions employed the use of CPGs is supported, especially in patients considered unfit for conventional surgery.

\title{
FM1.5
}

Aortic surgery in patients with combined abdominal aortic aneurysm and aortoiliac occlusive disease is associated with a high 30-day and 1-year mortality

\section{S. Richarz ${ }^{l}$, E. Mujagic ${ }^{1}$, P. Stierli ${ }^{2}$, L. Gürke ${ }^{l}, T$. Wolff $^{l}\left({ }^{1}\right.$ Basel, $^{2}$ Aarau $)$}

Objective: It is well known that aortic surgery for abdominal aortic aneurysm (AAA) is associated with a higher perioperative mortality than aortic surgery for aortoiliac occlusive disease (AIOD). The present study aims to investigate whether patients suffering from a combination of AAA and AIOD have a particularly bad outcome.

Methods: We performed a retrospective analysis of all elective or urgent open surgical procedures to the abdominal aorta from 2003 - 2013 at our institution. Patients operated for ruptured aortic aneurysm or acute leg ischemia (acute Leriche Syndrome) were not included in the analysis. 
Results: 312 patients were operated for AAA, 67 patients for AIOD and 25 patients for a combination of AAA and AIOD (12 patients with AAA as the primary indication for surgery and concomitant AIOD, 13 patients with AIOD as the primary indication for surgery and concomitant AAA). AAA patients and AAA+AIOD patients were older than patients with isolated AIOD (70.9y and 70.0y versus $62.8 \mathrm{y}$ ). 30 day follow-up was 100\%, 1 year follow-up for patients operated more than a year ago was $96.2 \%$. 30d mortality was $3.9 \%$ in the AAA group, $1.5 \%$ in the AIOD group and $8.0 \%$ in the AAA+AIOD group. 1y mortality was $6.7 \%$ in the AAA group, $1.7 \%$ in the AIOD group and $13.6 \%$ in the AAA+AIOD group. All deaths in the AAA+AIOD group were due to extensive mesenteric ischemia.

Conclusion: This is the first study in the literature investigating the outcome of aortic surgery in patients with a combination of AAA and AIOD. 30d mortality and 1y mortality was very high in these patients, suggesting that they carry a particularly high atherosclerotic burden. Mesenteric ischemia was the prominent severe complication. In AIOD patients, the aortic anastomosis of aorto-bifemoral bypass is commonly performed end-to-side and thus perfusion of the inferior mesenteric artery, the lumbar arteries and the hypogastric arteries is not affected. It is conceivable that the loss of lumbar arteries and the inferior mesenteric artery associated with AAA surgery is more problematic in patients with preexisting occlusion of the internal iliac arteries or relevant disease to the superior mesenteric artery, as is common in AIOD. Further analysis of the non-lethal surgical complications in the different groups is planned and may help to explain the observed differences.

\section{FM1.6}

\section{Outcome in patients with blunt aortic injury undergoing endovascular treatment}

\section{Makaloski, R. Bühlmann, D-D. Do, J. Schmidli (Bern)}

Objective: To analyse our experience of thoracic endovascular aortic repair in patients with blunt injury of the proximal descending aorta.

Methods: Consecutive case series of all patients referred to our hospital with blunt traumatic aortic injury between January 2005 and December 2013. Patients were registered prospectively and analysed regarding demographic data, operative variables and early as well as long-term outcomes. Patients were followed by CT angiography before discharge, at 12 months and two years thereafter. Long-term outcome was analysed in terms of reintervention rate and survival.

Results: Twenty five patients with traumatic aortic injury undergoing thoracic endovascular aortic repair (TEVAR) were analysed. Median age was 45 years (range, 28-66 years) and 22 were males (88\%). Twenty one patients were treated acutely within 24 hours (84\%), 3 patients subacutely within 1 week $(12 \%)$ and in one patient $(4 \%)$ the injury had been missed initially. This patient was treated one year after the accident when he presented with a large intimal flap. Overall, two patients died (8\%): one before the stentgraft could be implanted and the other died on the 5th postoperative day from brain injury. In 13 patients (52\%) the left subclavian artery (LSA) was intentionally covered (6 of them were additionally occluded with a vascular plug). Only three patients (12\%) received a left carotidsubclavian bypass in the emergency situation. None of the patients suffered from stroke or spinal cord ischemia. Median hospital stay was 11 days (range, 2-62 days). During follow-up (median of 34 months (1-104 months) no reintervention or death was registered. In the patients with covered LSA no long-term negative consequences were observed.

Conclusion: Endovascular treatment of traumatic aortic injury in the descending aorta is an effective treatment option in severely injured patients. Even if the LSA must be covered to create a suitable landing zone for the stentgraft, functional long-term results remain very acceptable. 


\section{Grundlagen, Methoden und Medikation Fondements, méthodes et médication}

\section{FM2.1}

Atorvastatin treatment improves impaired walking capacity in experimental peripheral artery disease: Effect on hindlimb perfusion and on local and systemic inflammatory state

\section{Pellegrin, K. Bouzourène, J.-F. Aubert, C. Amstutz, L. Mazzolai (Lausanne)}

Objective: Statin benefits in primary and secondary prevention of coronary heart disease are well established. Weather their use is also beneficial in lower limb impairment of patients with peripheral artery disease (PAD) remains unclear. Using a mouse model of PAD, we investigated cholesterolindependent effects of atorvastatin treatment on walking capacity and examined potential underlying mechanisms.

Methods: Mouse model of PAD was induced in hypercholesterolemic/atherosclerotic ApoE knockout mice by right common iliac artery surgical ligation. One week post-ligature, mice were treated with or without atorvastatin $(20 \mathrm{mg} / \mathrm{kg} / \mathrm{day}$ in drinking water) for 4 weeks. Walking capacity of mice and hindlimb perfusion were assessed using a 24-hour free walking test and laser Doppler imaging before ligature, and at weeks 1, 3, and 5 post-ligature. At week 5 post-ligature, quantitative real-time RT-PCR was used to determine mRNA expression of pro-inflammatory cytokines TNF-alpha, IL1 beta and IL-12p35 as well as markers of pro-inflammatory M1 and anti-inflammatory M2 macrophages (CD11c and CD206, respectively) in gastrocnemius muscle and/or in spleen.

Results: Following artery ligation, untreated mice showed significantly and chronically reduced $24 \mathrm{~h}$ total walking distance and hindlimb ischemia. Atorvastatin treatment significantly improved the $24 \mathrm{~h}$ total walking distance by $165 \%$ and $217 \%$ at weeks 3 and 5 post-ligature, respectively. Compared to untreated mice, ischemic hindlimb perfusion recovery was significantly increased and ischemic muscle arteriolar density tended to be higher $(+143 \%)$ in atorvastatin-treated mice. A significant TNFalpha, IL-1beta and IL-12p35 ischemic muscle mRNA expression reduction was observed in atorvastatin-treated mice compared to non-treated ones. Atorvastatin significantly decreased by $74 \%$ the ratio of CD11c to CD206 mRNA expression (a marker of M1/M2 macrophage balance) in spleen, but not in ischemic muscle. Plasma cholesterol and ischemic muscle fiber area did not significantly differ between groups.

Conclusion: Atorvastatin treatment significantly improves impaired walking capacity in a PAD mouse model. Underlying mechanisms include stimulation of ischemic hindlimb functional revascularization, decreased muscle pro-inflammatory cytokines expression, and systemic polarization of macrophages towards a less pro-inflammatory phenotype.

\section{FM2.2}

Voluntary running exercise slows the progression and stabilizes established Angiotensin IIdependent advanced atherosclerotic lesions

\section{Pellegrin, J.-F. Aubert, K. Bouzourène, C. Amstutz, L. Mazzolai (Lausanne)}

Objective: We have previously demonstrated that exercise training prevents the development of Angiotensin (Ang) II-induced atherosclerosis and vulnerable plaques in ApoE knock-out mice. In the present study, we investigated whether exercise training attenuates the progression of pre-existing Ang II-dependent atherosclerosis.

Methods: ApoE knock-out mice were subjected to left renal artery clipping (2-kidney, 1-clip [2K1C] renovascular hypertension model) for 4 weeks to induce the formation of Ang II-dependent advanced and vulnerable lesions. Subsequently, 2K1C mice were randomized into either a sedentary control 
group (SED) or an exercise group (voluntary wheel running, EX) for 4 additional weeks. Physiological parameters, plaques size and stability, and gene expression of adhesion molecules (VCAM-1, ICAM1), cytokines (IL-18, IL-1beta, TNF-alpha, IL-10, IL-4), markers of Th1/Th2 balance (T-bet/Gata3), and markers of M1/M2 macrophage balance $(\mathrm{CD} 11 \mathrm{c} / \mathrm{CD} 206)$ in aortic and spleen tissues were determined at the end of the study.

Results: Average daily distance covered by EX mice was $7.1 \pm 0.4 \mathrm{~km}$. Mean blood pressure and plasma renin activity did not significantly differ between the 2 groups. En face aorta analysis revealed a significant $66 \%$ plaque size reduction in EX compared to SED. Compared to CON, aortic sinus histological analysis showed a significant higher plaque stability score in EX (+98\%). EX significantly downregulated aortic mRNA expression of ICAM-1 and tended to decrease VCAM-1 one as measured by real-time quantitative RT-PCR. Spleen mRNA expression of pro-inflammatory cytokines IL18 and IL-1beta significantly decreased whereas expression of anti-inflammatory cytokine IL-4 significantly increased with EX. Neither Th1/Th2, nor M1/M2 mRNA expression markers was modulated by EX.

Conclusion: Voluntary exercise is effective in slowing the progression and stabilizing established Ang II-dependent advanced lesions. Underlying molecular mechanisms include a decrease in vascular proatherogenic adhesion molecules expression and an amelioration of systemic cytokines expression profile.

\section{FM2.3}

\section{Diagnostic performance of $18 F$ FDG PET/CT in vascular graft infection}

\section{Mayer, B. Sah, L. Husmann, R. Weber, Z. Rancic, B. Hasse (Zürich)}

Objective: The aim of this study was to evaluate the diagnostic accuracy of positron emission tomography/computed tomography with 18F-fluorodeoxyglucose (FDG-PET/CT) in a population with suspected graft infection and to validate a new diagnostic imaging score for FDG-PET/CT.

Methods: Prospective cohort study. FDG-PET/CT was performed prospectively in 30 patients with suspected graft infection, in 13 of them prior to start of antimicrobial treatment. Diagnostic accuracy was assessed using a new 5-point-likert-scale for visual grading and by using a binary score. SUV max. values were calculated for quantitative measurements of metabolic activity, and cut-off points were calculated using receiver operator curve (ROC). The standard of reference was a microbiological culture, obtained after open biopsy or graft explantation.

Results: Sensitivity, specificity, positive predictive value (PPV), negative predictive value (NPV), and accuracy of PET/CT for the diagnosis of graft infections was $100 \%, 86 \%, 96 \%, 100 \%$, and $97 \%$, respectively. Using the new scale, FDG-PET/CT correctly recognized 23 patients with graft infection, one patient was diagnosed false-positive, six patients were correctly classified as true-negative, and no patients were rated false-negative. Using a previously established binary score, sensitivity, specificity, PPV, NPV, and accuracy was $96 \%, 86 \%, 96 \%, 86 \%$ and $93 \%$, respectively. ROC analysis suggested a SUV max. cutpoint value of 3.7 to differentiate between infected and non-infected grafts $(\mathrm{p}<0.001)$. Additionally, FDG-PET/CT provided a conclusive clinical diagnosis in six out of seven patients without graft infection (i.e. other sites of infections or malignancy).

Conclusion: The diagnostic accuracy of FDG-PET/CT in the detection of aortic graft infection is high. A newly introduced visual grading score and early imaging prior to antimicrobial treatment may further improve the diagnostic accuracy. 
FM2.4

Long-term follow-up after endovascular revascularization for acute limb ischemia: a retrospective single-center cohort study

\section{F. Johner, M. Husmann, B. Seifert, B. Amann-Vesti (Zürich)}

Objective: The aim of this retrospective single-center study was to evaluate the long-term outcome of patients with acute limb ischemia after endovascular treatment. Primary endpoints were target vessel revascularization (TVR), non-target extremity revascularization (NTER), amputation, major vascular events (acute coronary syndrome, stroke), coronary artery revascularization (PCI or CABG) and (amputation-free) survival.

Methods: 436 catheter-based interventions for acute limb ischemia performed at a tertiary referral center in Switzerland were identified between 2004 and 2010. Follow-up data of 303 patients were available for this study (mean age $68.5 \pm 12.7$ years, $40 \%$ female). The mean follow-up time was 38.7 \pm 26.17 months. Event history and survival analyses were executed using the Kaplan-Meier method. Results are given as cumulative proportions with standard errors estimated by Kaplan-Meier analysis.

Results: TVR is estimated to have been performed in $40.1 \pm 2.9 \%$ after 1 year, increasing up to 66.5 $\pm 3.8 \%$ after 5 years. The median TVR time was 24 months. The probability of having undergone NTER 1 year after presentation was $7.1 \pm 1.5 \%$ and reached $29.2 \pm 4 \%$ after 5 years. The estimated proportion of patients who needed major or minor amputation was $4.3 \pm 1.2 \%$ after 1 year and increased to $9 \pm 2.1 \%$ after 5 years. Major vascular events such as acute coronary syndrome or stroke are estimated to have occurred in $2.1 \pm 0.8 \%$ and $1.4 \pm 0.7 \%$ after 1 year and $4.6 \pm 1.6 \%$ and $4.7 \pm$ $1.7 \%$ after 5 years respectively. $2.1 \pm 1 \%$ and $10.6 \pm 2.5 \%$ are estimated to have received coronary artery revascularization after 1 and 5 years respectively. Amputation-free survival is expected at 90.3 $\pm 1.8 \%$ after 1 year and $74.8 \pm 3.2 \%$ after 5 years. The cumulative proportion surviving 1 year following acute limb ischemia was $95.4 \pm 1.2 \%$. After 5 years, $79.7 \pm 3.1 \%$ are estimated to be alive. Conclusion: TVR following acute limb ischemia is common and most likely to be performed within the first two years after presentation. NTER is less common, but still occurred in about $20 \%$ of the patients after four years. Fortunately, amputations and major vascular events are rare. Amputation-free survival and cumulative survival of approximately $75 \%$ and $80 \%$ respectively after 5 years are high.

Table 1: Baseline Characteristics of $n=303$ patients with acute limb ischemia

\begin{tabular}{|l|l|l|}
\hline Characteristics & N & Value \\
\hline Male / female, $\mathrm{n}(\%)$ & 303 & $182(60) / 121(40)$ \\
\hline Age, years (mean $\pm \mathrm{SD})$ & 303 & $68.5 \pm 12.7$ \\
\hline BMI, kg/m2 (mean $\pm \mathrm{SD})$ & 292 & $25.7 \pm 5.0$ \\
\hline Creatinine, $\mu \mathrm{mol} / \mathrm{l}(\mathrm{mean} \pm \mathrm{SD})$ & 302 & $89.7 \pm 37.2$ \\
\hline eGFR & 302 & \\
$60 \mathrm{ml} / \mathrm{min} / 1.73 \mathrm{~m}^{2}, \mathrm{n}(\%)$ & & $220(73)$ \\
$30-59 \mathrm{ml} / \mathrm{min} / 1.73 \mathrm{~m}^{2}, \mathrm{n}(\%)$ & & $75(25)$ \\
$<30 \mathrm{ml} / \mathrm{min} / 1.73 \mathrm{~m}^{2}, \mathrm{n}(\%)$ & & $7(2)$ \\
\hline Hemoglobin, mmol/l (mean $\pm \mathrm{SD})$ & 303 & $13.3 \pm 2.0$ \\
\hline Hypercholesterolemia, $\mathrm{n}(\%)$ & 303 & $234(77)$ \\
\hline Hypertension, $\mathrm{n}(\%)$ & 303 & $237(78)$ \\
\hline Smoker, $\mathrm{n}(\%)$ & 303 & $173(57)$ \\
\hline Diabetes, $\mathrm{n}(\%)$ & 303 & $66(22)$ \\
\hline Coronary artery disease, $\mathrm{n}(\%)$ & 303 & $87(29)$ \\
\hline Cerebrovascular disease, $\mathrm{n}(\%)$ & 303 & $53(18)$ \\
\hline Atrial fibrillation/flutter, $\mathrm{n}(\%)$ & 303 & $34(11)$ \\
\hline
\end{tabular}




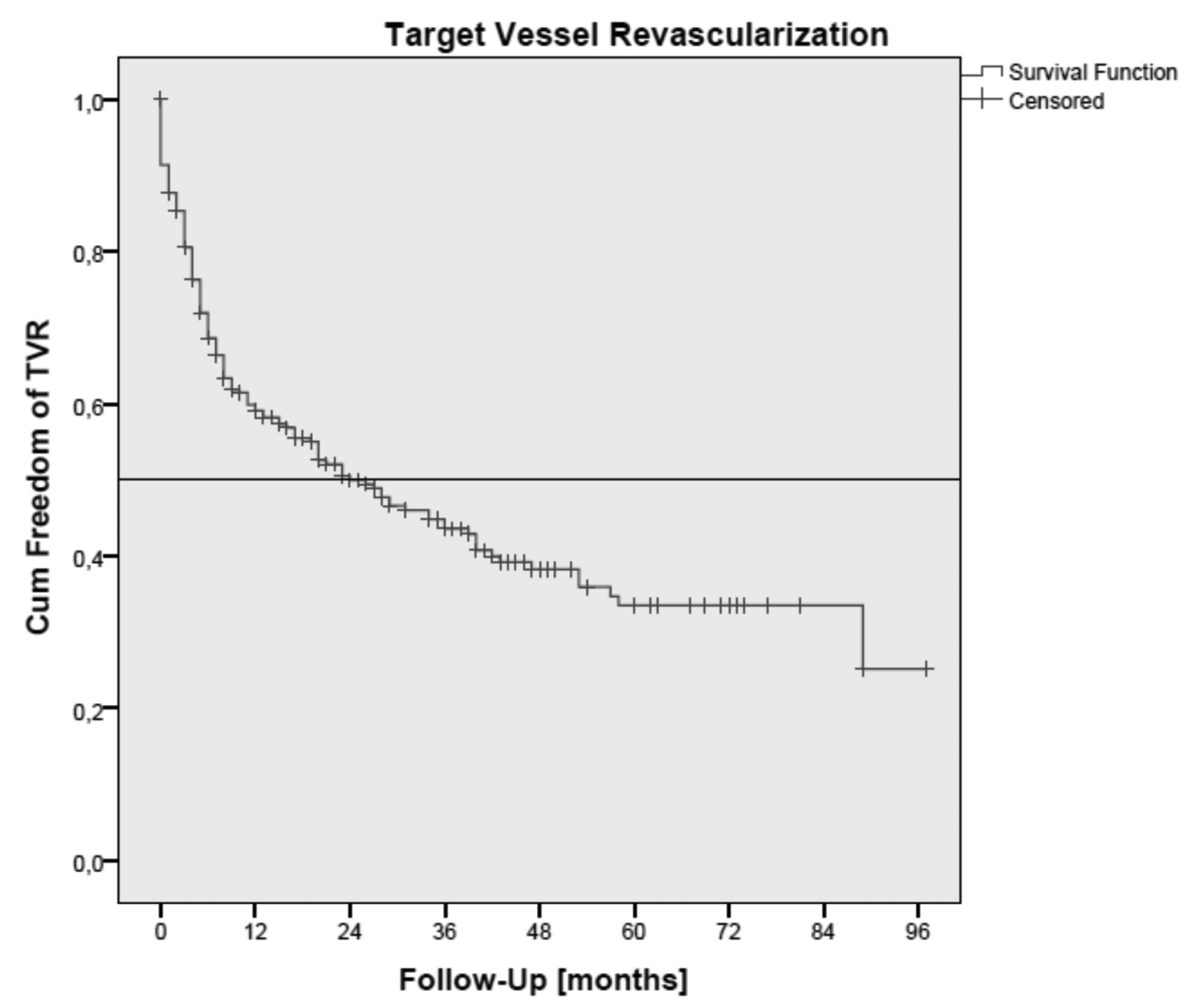

Figure 1: Kaplan-Meier estimate for freedom of TVR on follow-up N of remaining cases at 12, 24, 36, 48, 60 months: 151, 95, 72, 37, 27

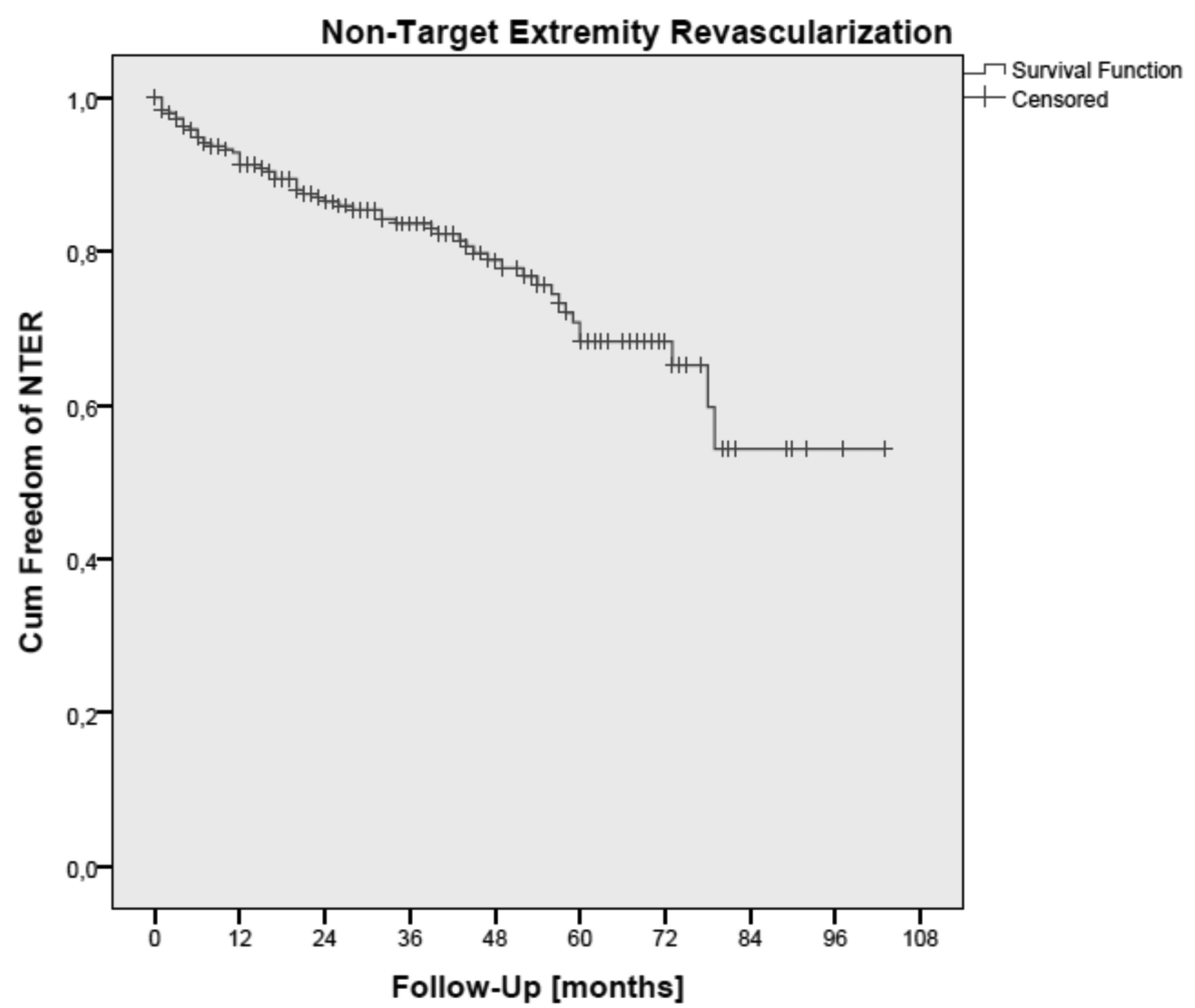

Figure 2: Kaplan-Meier estimate for freedom of NTER on follow-up N of remaining cases at 12, 24, $36,48,60$ months: $230,168,138,78,56$ 


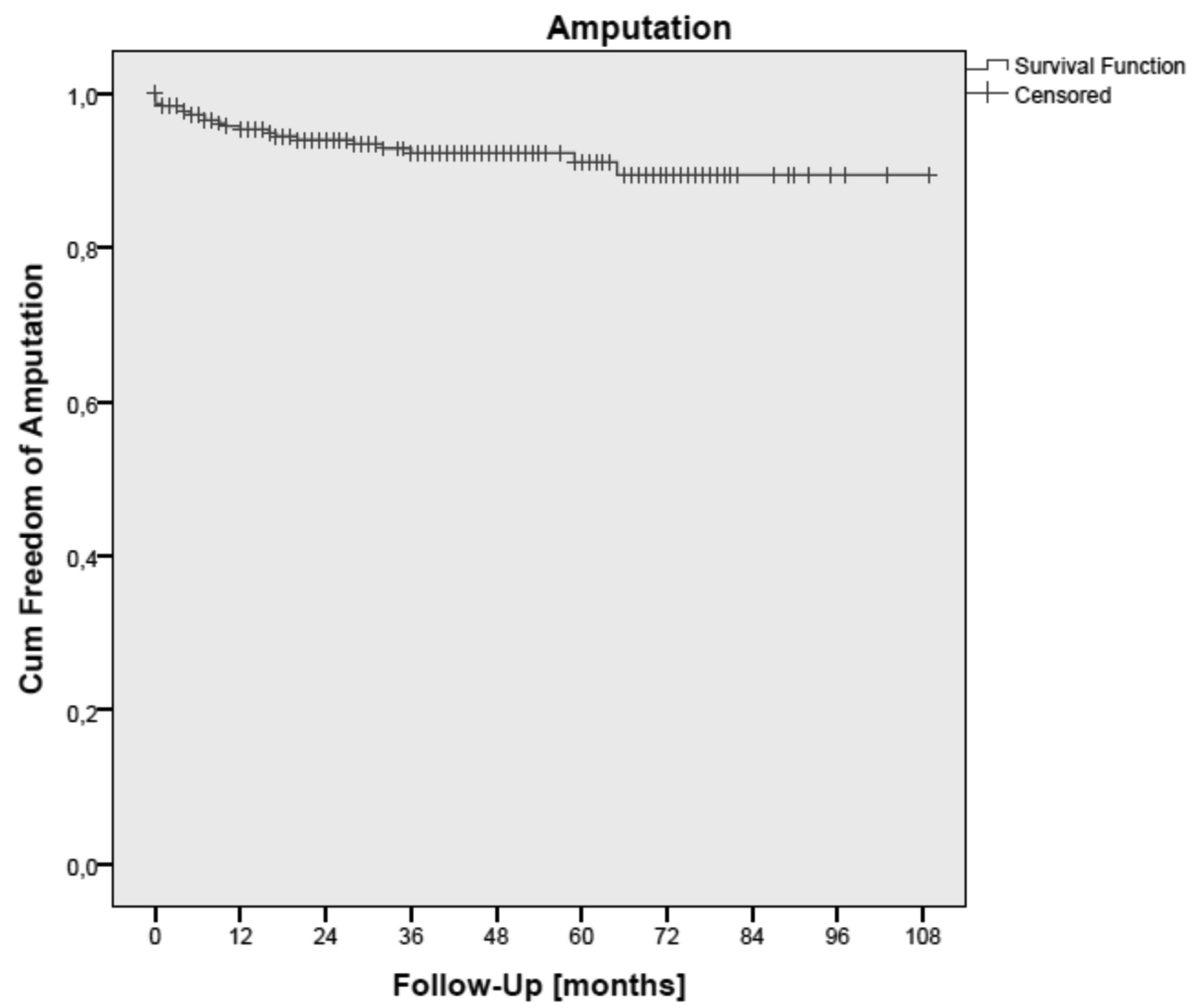

Figure 3: Kaplan-Meier estimate for freedom of amputation on follow-up $\mathrm{N}$ of remaining cases at 12, 24, 36, 48, 60 months: 239, 185, 154, 98, 73

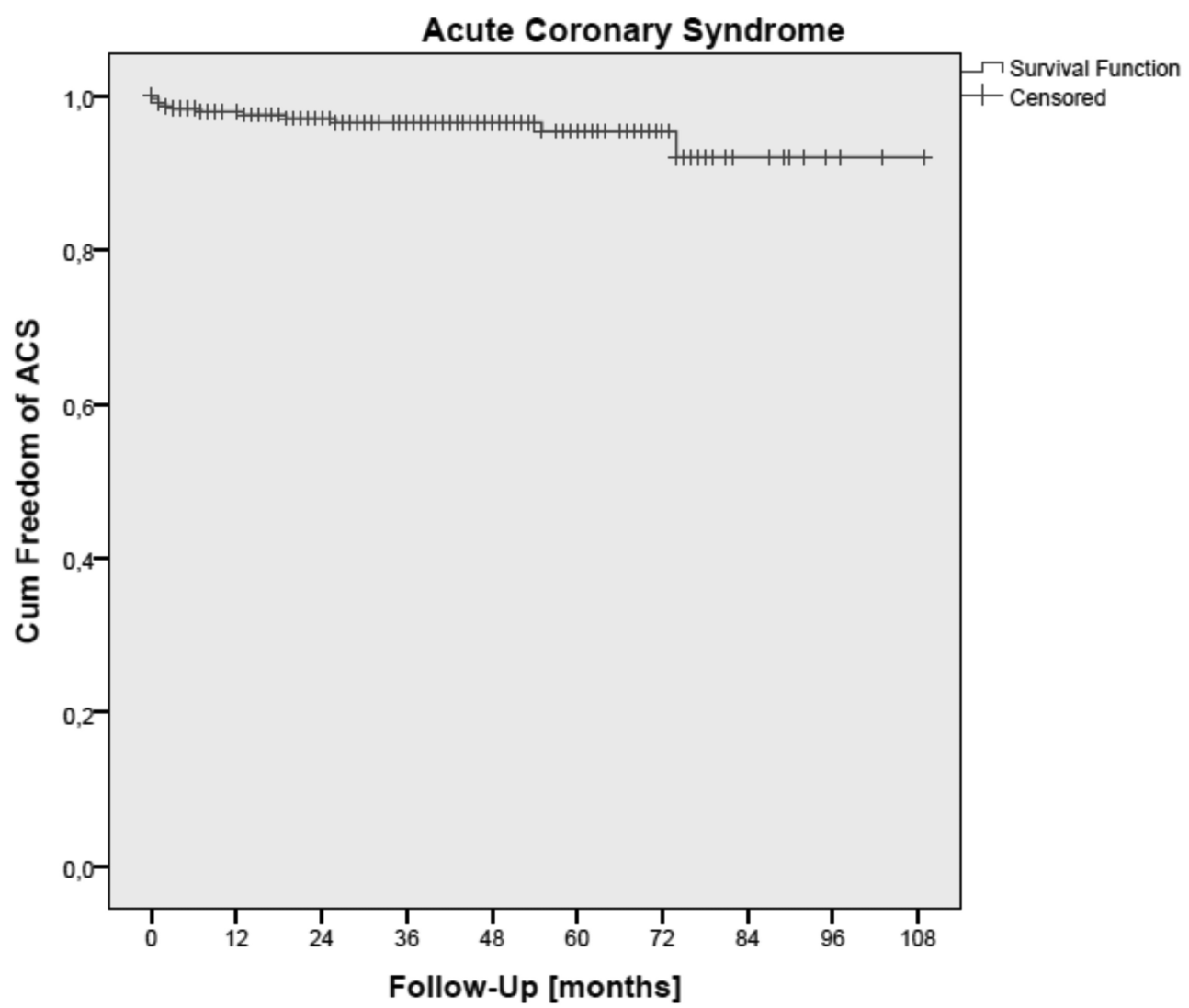

Figure 4: Kaplan-Meier estimate for freedom of ACS on follow-up $\mathrm{N}$ of remaining cases at 12, 24, 36, 48, 60 months: 243, 189, 159, 102, 73 


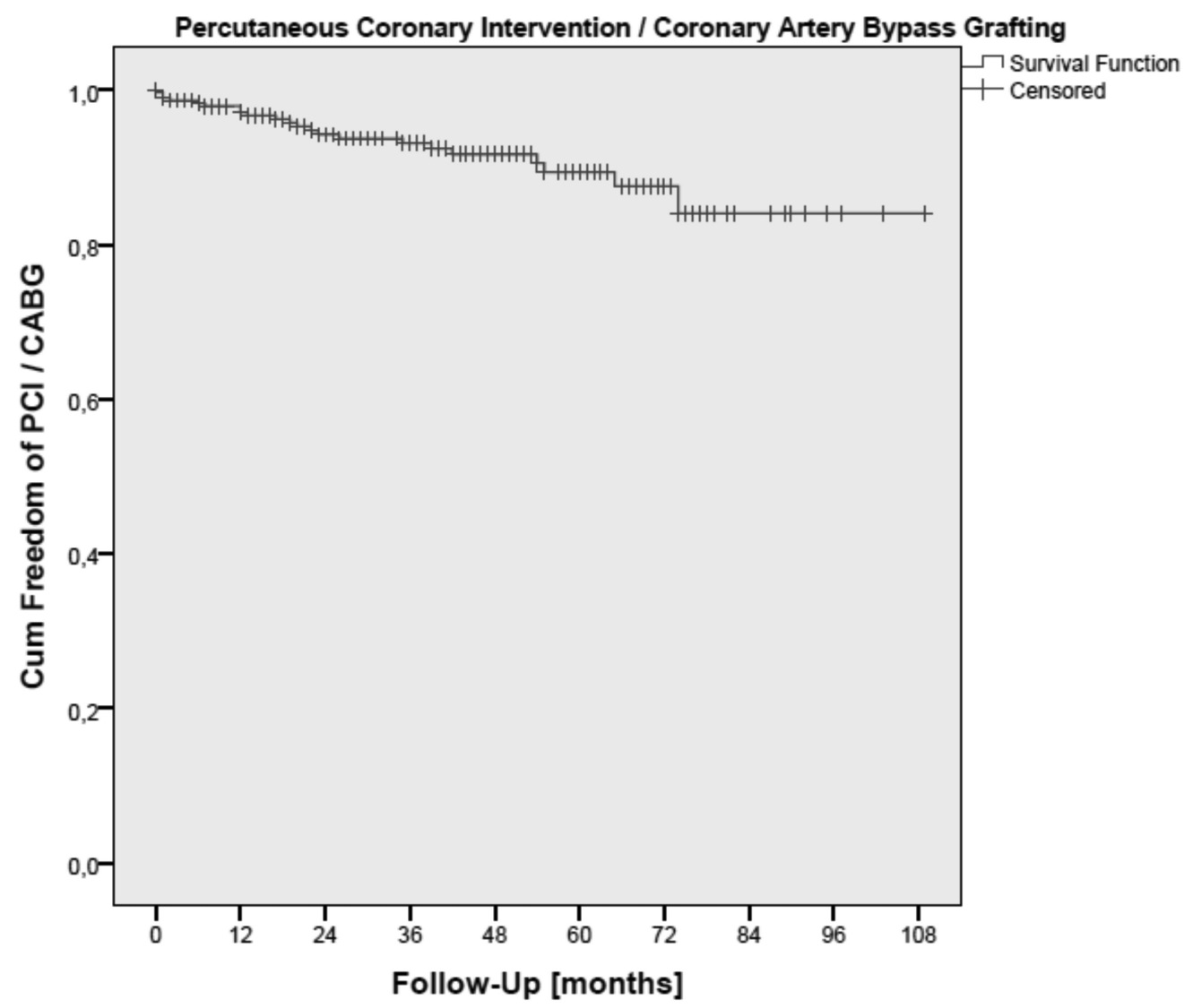

Figure 5: Kaplan-Meier estimate for freedom of PCI/CABG on follow-up N of remaining cases at 12, 24, 36, 48, 60 months: 243, 181, 150, 93, 66

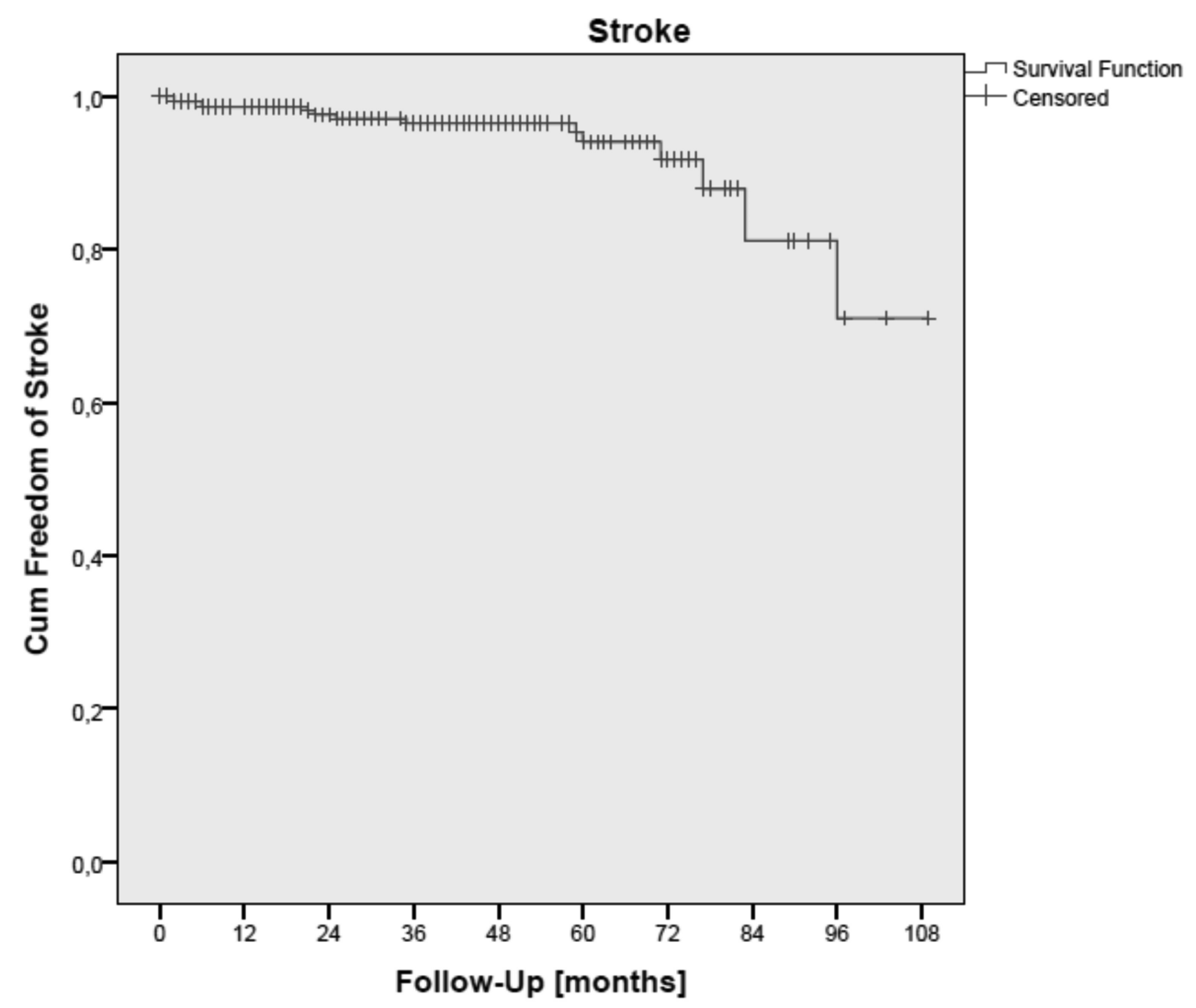

Figure 6: Kaplan-Meier estimate for freedom of stroke on follow-up $\mathrm{N}$ of remaining cases at 12, 24, 36, 48, 60 months: $245,190,159,103,76$ 


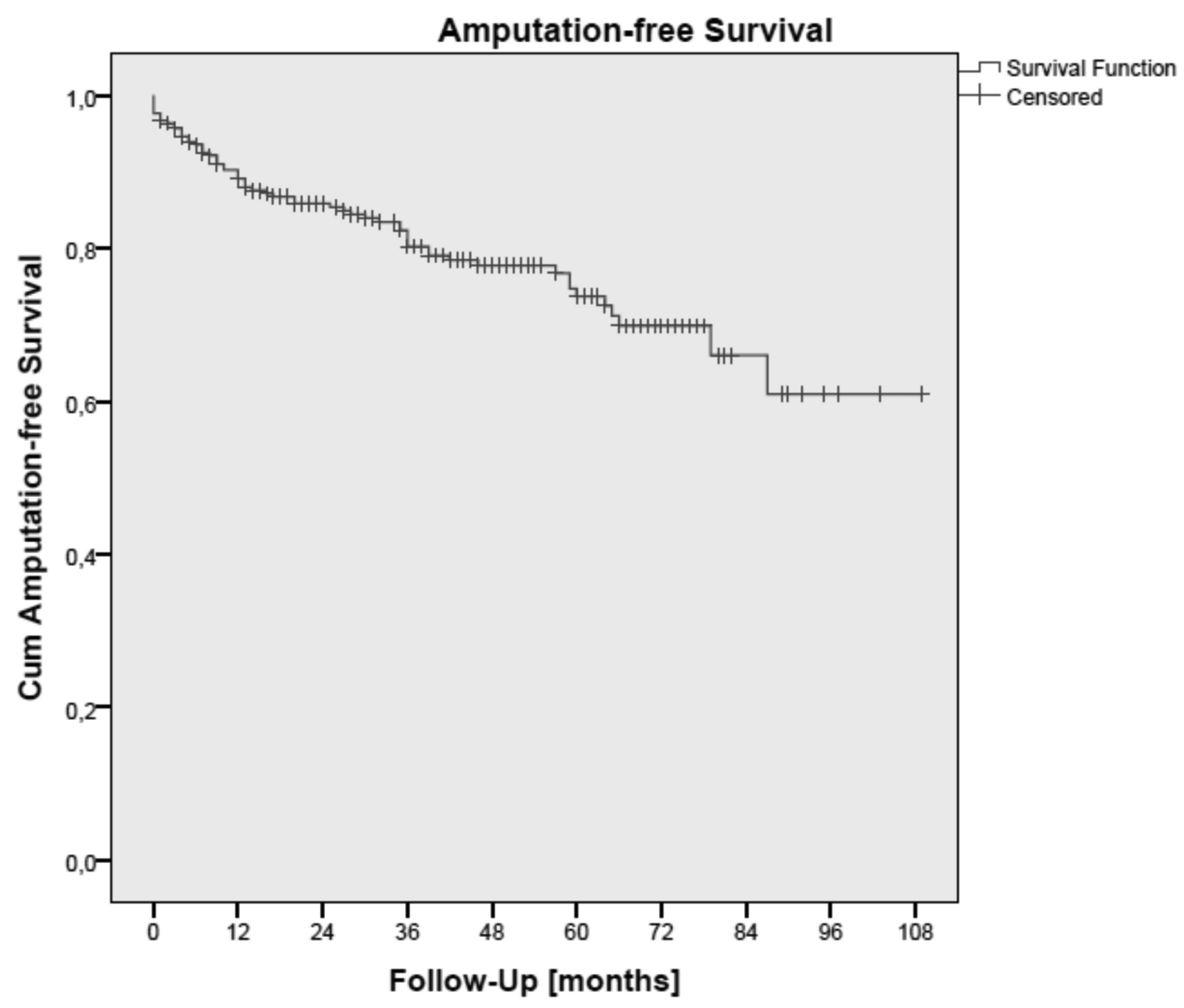

Figure 7: Kaplan-Meier estimate for amputation-free survival $\mathrm{N}$ of remaining cases at $12,24,36,48$, 60 months: $239,185,154,98,73$

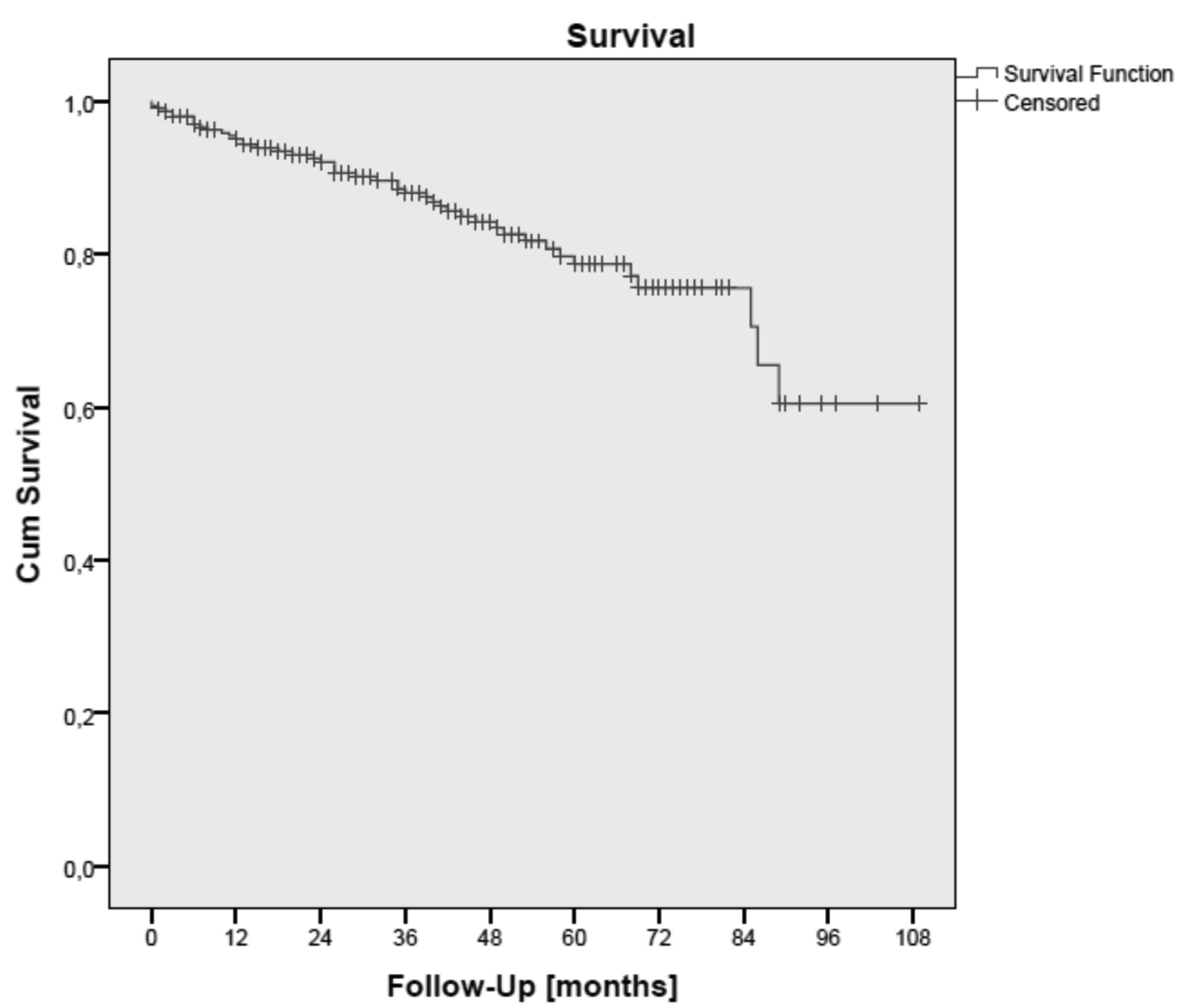

Figure 8: Kaplan-Meier estimate for survival $\mathrm{N}$ of remaining cases at 12, 24, 36, 48, 60 months: 250, $197,165,106,77$ 


\section{FM2.5}

\section{Carotid-femoral and brachial pulse wave velocities in peripheral arterial disease}

M. Frick ${ }^{l}$, V. Jacomella ${ }^{1}$, S. Roth ${ }^{l}$, I. B. Wilkinson ${ }^{2}$, B. Amann-Vesti ${ }^{1}$, N. Ulmer ${ }^{1}$, M. Husmann ${ }^{1}$ $\left({ }^{l}\right.$ Zürich, ${ }^{2}$ Cambridge)

Objective: Pulse wave velocity (PWV) is a marker for arterial stiffness and cardiovascular risk. Peripheral arterial disease (PAD) is associated through its extensive atherosclerotic burden with both increased arterial stiffness and cardiovascular events. Recently, different non-invasive assessment devices that measure carotid-femoral or brachial PWV have become commercially available. To compare PWV derived from carotid-femoral (cfPWV) or brachial (bPWV) assessments in patients with PAD.

Methods: Measurements of pulse wave velocities with the two different non-invasive methods were performed as part of standard of care assessment in outpatients with PAD. Pulse wave velocities were assessed as bPWV by Mobil-O-Graph (ABPM by IEM; Stolberg, Germany), which is a brachial cuffbased method and as cfPWV by Vicorder (SMT Medical, Würzburg, Germany) an oscillometric technique for carotid and femoral pulse wave assessment. Differences between the two methods were compared by Mann Whitney U test and Bland Altmann plot. Spearman rank correlation was performed to test for age dependency.

Results: In 67 Patients (35.8\% female, mean age 69, range 39-91 years) bPWV (mean $10.5 \pm 2.4 \mathrm{~m} / \mathrm{s}$ ) was significantly higher than cfPWV (mean $9.2 \pm 2.1 \mathrm{~m} / \mathrm{s})(\mathrm{p}=0.0013)$ (Table 1 and Figure1). Brachial PWV showed a significant correlation with age $(\mathrm{r}=0.935, \mathrm{p}=<0.0001)$ whereas cfPWV did not $(\mathrm{r}=0.311, \mathrm{p}=0.116)$ (Figure $2 \mathrm{a}$ and $\mathrm{b}$ ). Figure 3 shows Bland Altmann plot comparing bPWV against cfPWV indicating a mean difference of -10.4(+2 SD (4.31);-2 SD (-6.38))

Conclusion: The gold standard assessment (cfPWV) differs from brachial PWV and lacks correlation with age. Aorto-femoral atherosclerotic burden may in part explain this finding since these segments impact the difference in transit time in the femoral segment.

Table 1

Characteristics of 67 patients with peripheral arterial disease:

\begin{tabular}{|c|c|c|}
\hline Age, yrs & 69 & $(39-91)$ \\
\hline $\mathrm{BMI}, \mathrm{kg} / \mathrm{m}^{2}$ & 27 & $(17-44)$ \\
\hline \multicolumn{3}{|l|}{ Blood pressure, $(\mathrm{mmHg})$} \\
\hline systole & 140 & $(110-195)$ \\
\hline siastole & 83 & $(64-110$ \\
\hline pulse pressure & 57 & $(26-99)$ \\
\hline \multicolumn{3}{|l|}{ Cardiovascular Risk factor, } \\
\hline Diabetes mellitus & 21 & (31) \\
\hline Dyslipidemie & 36 & (53) \\
\hline Hypertension & 51 & $(76)$ \\
\hline Ever Smoking & 51 & $(76)$ \\
\hline Positive familiy history & 18 & $(27)$ \\
\hline \multicolumn{3}{|l|}{ Cardiovasc. Comorbidities } \\
\hline CAD & 24 & $(36)$ \\
\hline $\mathrm{CVI}$ & 13 & (19) \\
\hline
\end{tabular}

Data are mean (range) for quantitative variables and number (percentage) for categorical variables. $C A D=$ coronary arteria disease $; C V D=$ Cerebrovascular disease. 


\section{Figure 1}

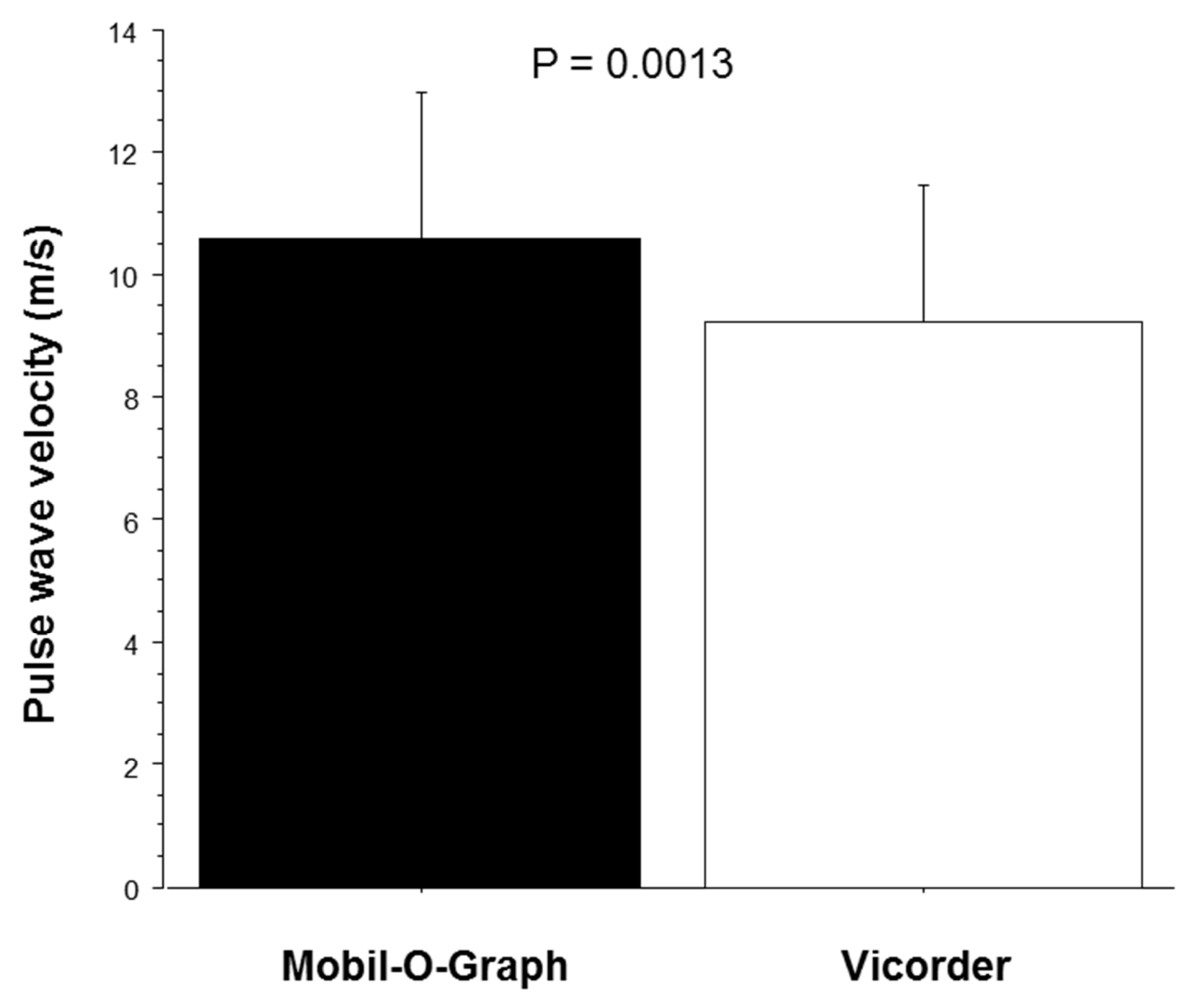

Figure $2 \mathrm{a}$

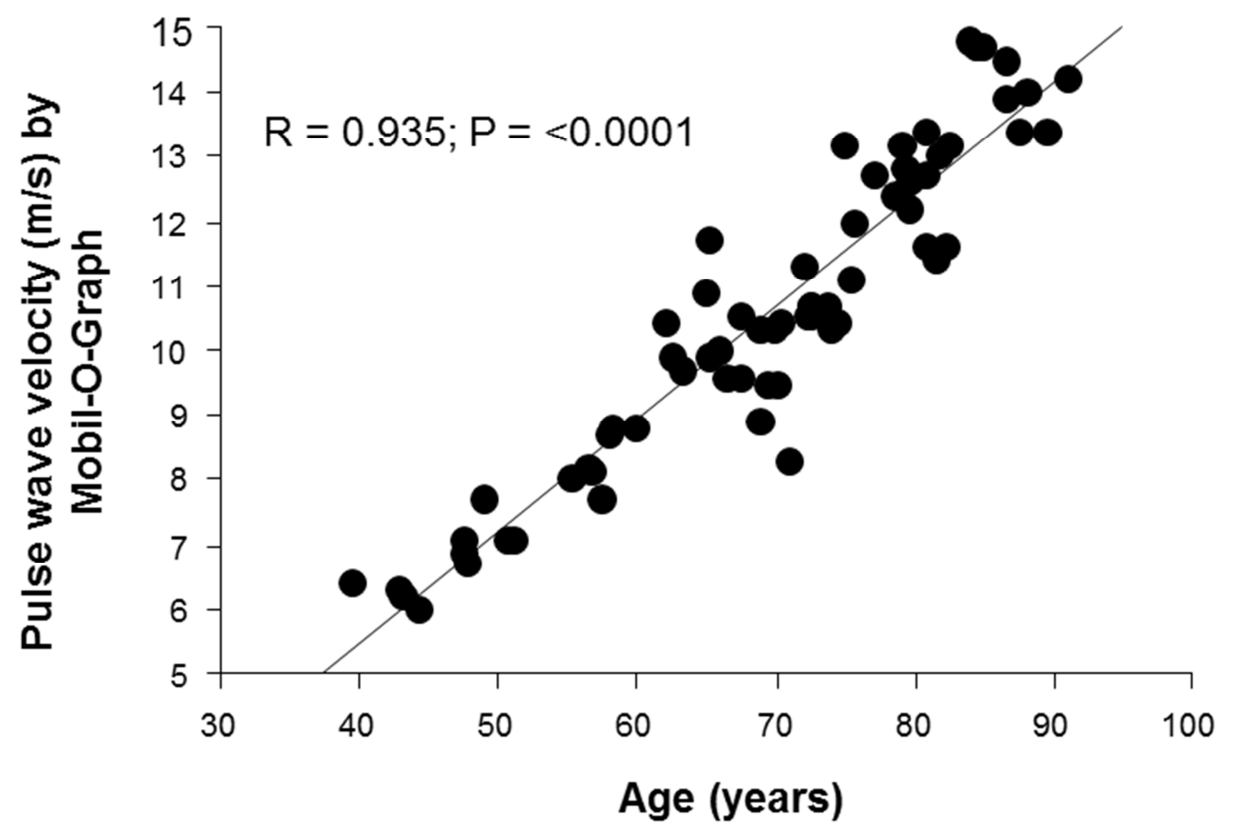


Figure $2 b$

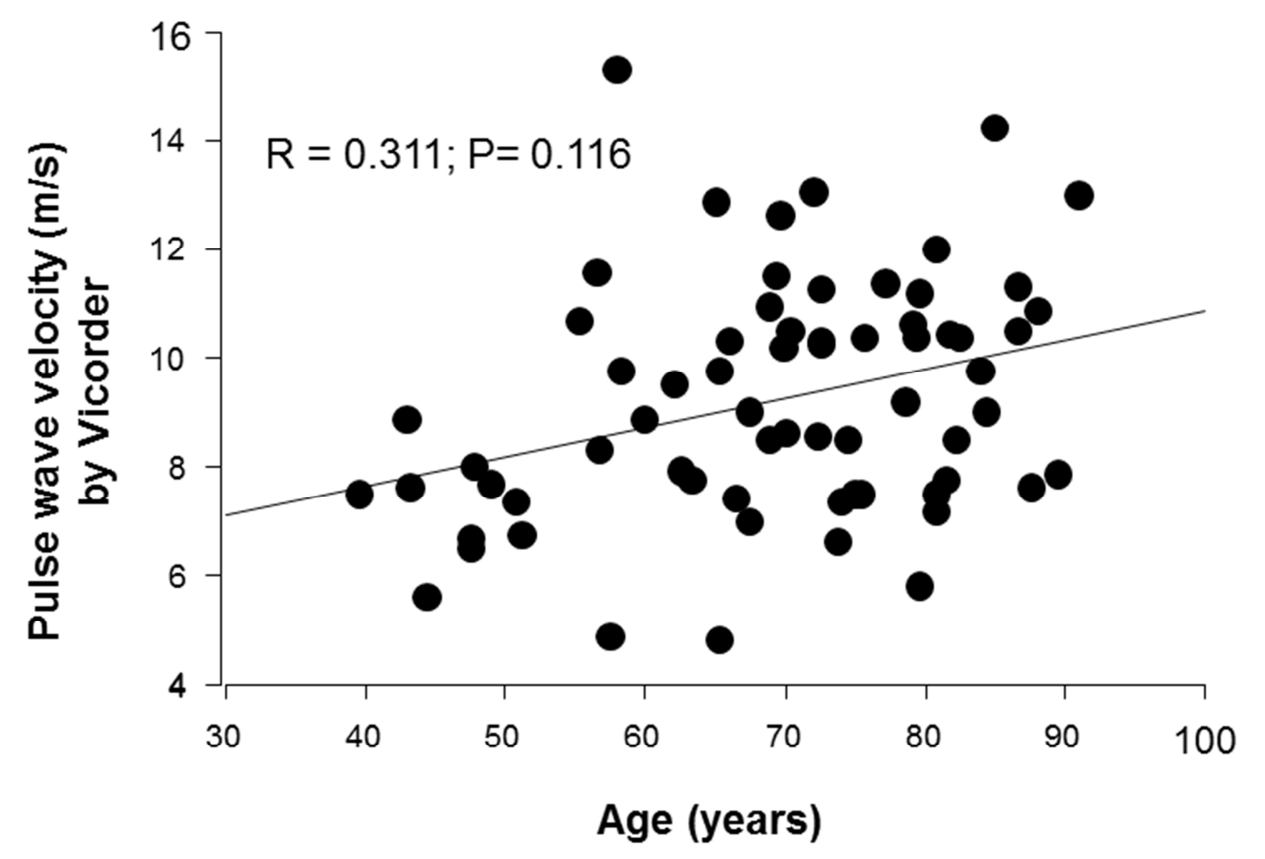

Figure 3

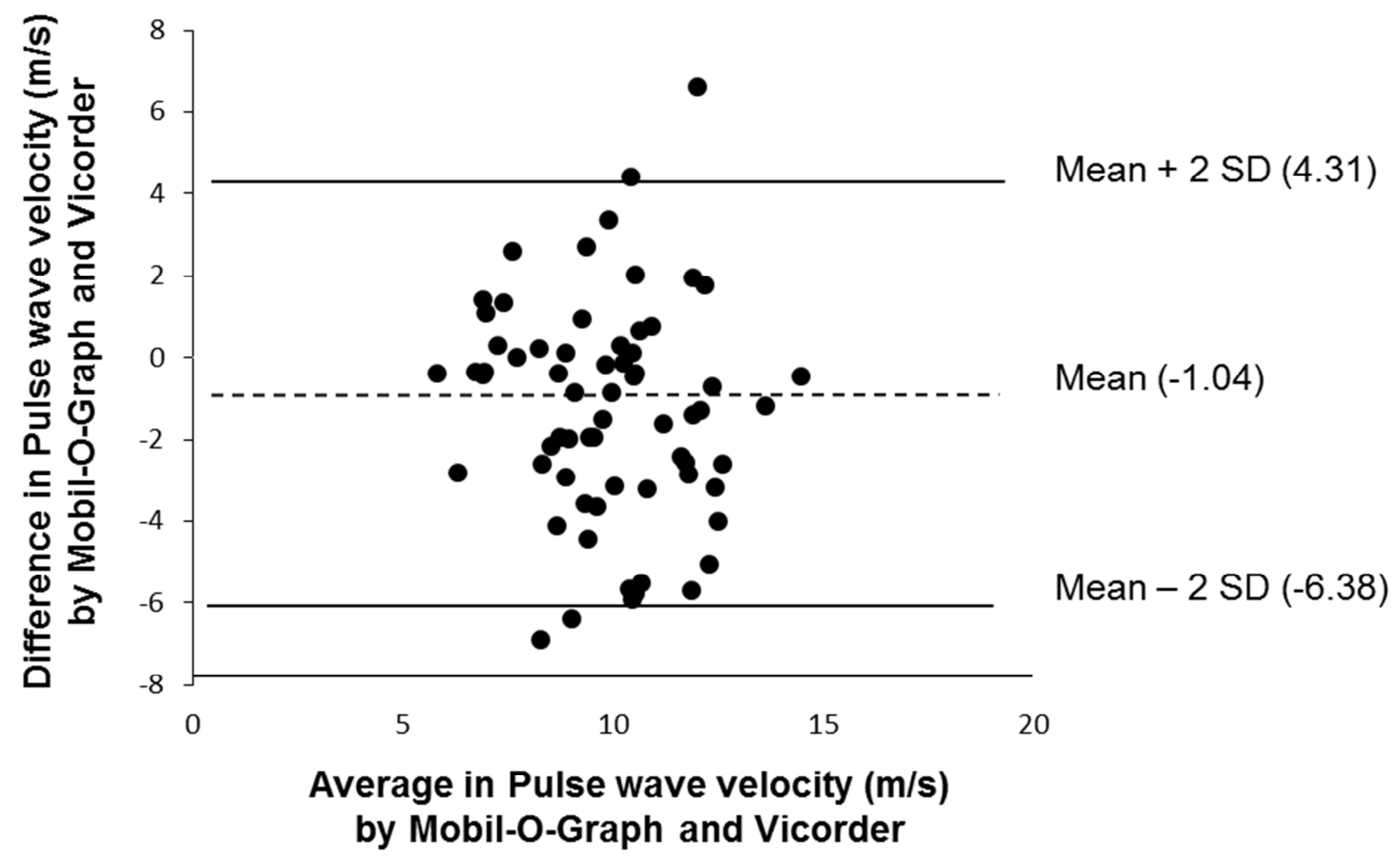


Figure 4

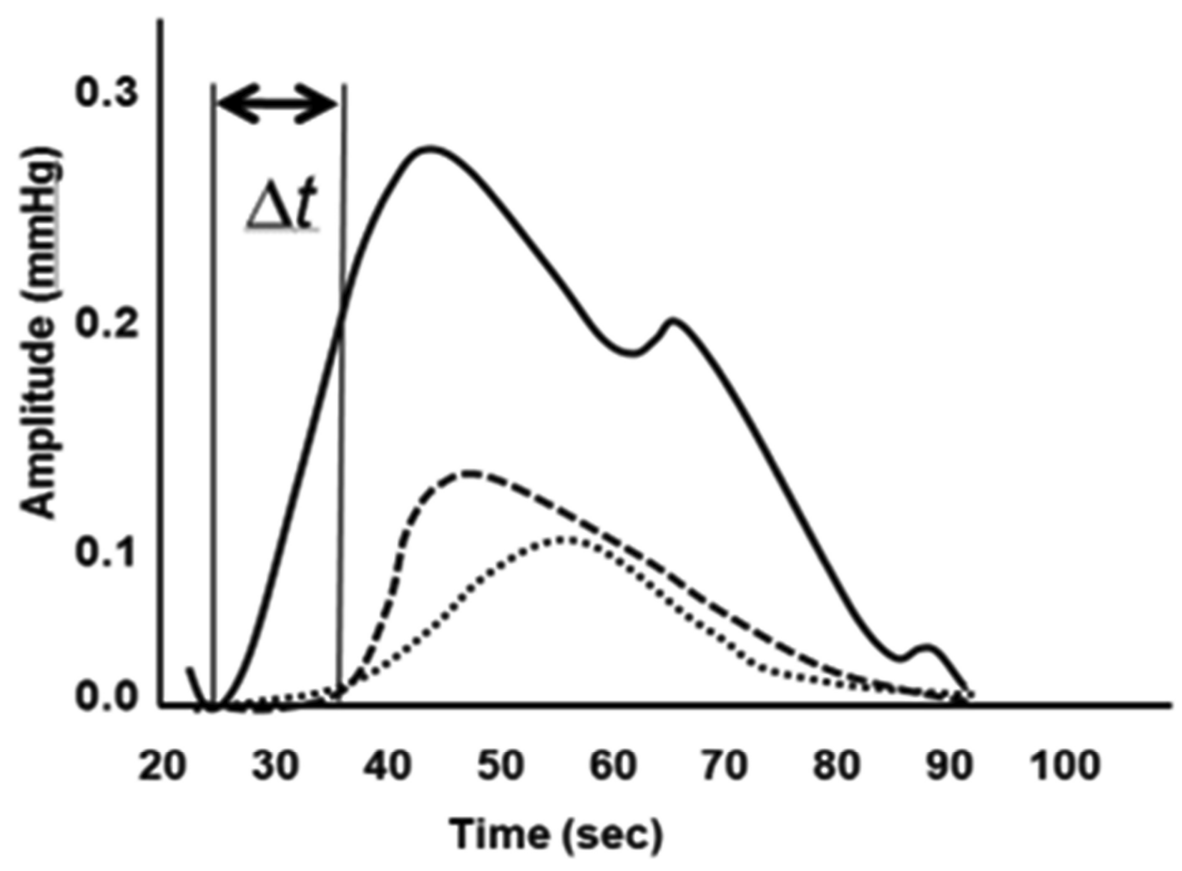

FM2.6

Radioprotective light-weight caps in fluoroscopy-guided interventions: a randomized controlled trial

H. Uthoff, A. Kreusch ${ }^{2}$, R. Quesada ${ }^{3}$, D. Staub ${ }^{1}\left({ }^{1}\right.$ Basel, ${ }^{2}$ Winterthur, ${ }^{3}$ Miami)

Objective: To test the radioprotection efficacy and comfort of newer bilayer barium sulfate-bismuth oxide composite (XPF) caps in fluoroscopy-guided interventions.

Methods: Institutional review board approval and written informed consent were obtained for this HIPAA-compliant study, and 197 measurements including 548 fluoroscopy-guided interventions were performed, with operators randomly assigned to wear standard (fabric) $(\mathrm{n}=59), 0.3 \mathrm{~mm}(\mathrm{n}=74)$ or $0.5 \mathrm{~mm}(\mathrm{n}=64)$ lead-equivalent XPF caps. Radiation doses were measured by using dosimeters placed outside and underneath the caps. Wearing comfort was assessed at the end of each procedure on a visual analog scale (0-100, with 100 indicating optimal comfort).

Results: Procedure data did not differ between the XPF and standard groups. Mean standard, XPF$0.3 \mathrm{~mm}$ and XPF- $0.5 \mathrm{~mm}$ cap weights were $12.5 \mathrm{~g}$ (95\%-CI 12.5 to $12.6 \mathrm{~g}$ ), $118.4 \mathrm{~g}$ (95\%-CI 116.7 to $120.3 \mathrm{~g})$ and $123.7 \mathrm{~g}(95 \%$-CI 122.9 to $124.6 \mathrm{~g})(\mathrm{p}<0.001)$, respectively. Comfort ratings for the XPF caps (median VAS 90, IQR 90-90) were not significantly lower compared with the comfort ratings for the standard caps (VAS 90, IQR 90-100; p=0.272). In 124/197 measurements including 375 cardiac procedures, the radiation expose was above the detector threshold. The mean radiation protection was $12.0 \% 95 \%$-CI 4.9 to $19.1 \%$ (standard caps, $\mathrm{n}=35$ ), $91.5 \%$ 95\%-CI 87.4 to $95.6 \%$ (XPF $0.3 \mathrm{~mm}$ caps, $\mathrm{n}=45$ ) and $97.1 \%$ 95\%-CI 92.5 to $100 \%$ (XPF $0.5 \mathrm{~mm}$ caps $(\mathrm{n}=44)(<=0.001$ for all group comparisons).

Conclusion: Lightweight XPF caps showed comparable comfort to standard fabric caps, but provide substantial radiation protection during fluoroscopy-guided interventions. 


\section{Venöse und lymphatische Erkrankungen \\ Pathologies lymphatiques et veineuses}

\section{FM3.1}

Reconstruction of non-functional lymph node basins using microvascular lymph node transfer in chronic lymphedema

$\underline{\text { Y. Harder }}{ }^{1,2}$, D. Müller ${ }^{2}$, M.-S. Kwak ${ }^{2}$, S. Wagner ${ }^{3}$, H.-G. Machens ${ }^{2}\left({ }^{1}\right.$ Lugano, ${ }^{2}$ München, ${ }^{3}$ Zurzach $)$

Objective: Chronic lymphedema requires lifelong conservative treatment that is only symptomatic and most often associated with significant loss of quality of life. So far, surgical treatment consisted of ablative surgery and of microvascular transplantation of lymph vessels or lympho-venous anastomoses. Though, the high morbidity and limited rate of decongestion have resulted in only little acceptance. Microvascular lymph node transfer without lympho-lymphonodular anastomosis represents a noteworthy alternative. The study aim was to analyse the efficacy of this surgery.

Methods: Between March 2011 and April 2014, 47 patients suffering from chronic lymphedema (27 legs; 19 arms; 1 face) and with maxed out complete physical decongestive therapy underwent 50 microvascular lymph node transfers (donor site (DS): 33x axilla; 17x groin; 2 bilateral cases; 2 consecutive transfers to the groin and the poplitea). Pre- and postoperative prospective data collection included patient history, photography and volumetry. Minimal follow-up was 3 months.

Results: 40 patients presented with secondary lymphedema, of which 27 patients had had adjuvant radiotherapy. Peri- and postoperative morbidity consisted of 4 hematomas (1x donor site; $3 \mathrm{x}$ recipient site (RS), 6 lymphoceles (5x DS; 1x RS), 4 wound infections (RS) and 6 wound breakdowns (3x DS and RS each). 6 of the 22 complications in 100 surgical sites required surgical revision. At 2 years, $50 \%$ of the patients describe improved mobility and all patients suffering from meteorosensitivity or pain were relieved by at least $67 \%$ respectively $40 \%$. Grade of compression, nocturnal wrapping and frequency of lymphatic drainage/week were reduced by $67 \%, 50 \%$ and $20 \%$, respectively. At 2 years, volume excess induced by lymphedema decreased by $28 \%$.

Conclusion: Microvascular lymph node transfer is associated with an acceptable surgery-related morbidity. It represents a valuable alternative or adjunct to current standard surgical procedures to treat chronic lymphedema with maxed out conservative treatment. The spontaneous restoration of lympho-lymphatic and lympho-venous anastomoses allows for functional reconstruction of the lymph node basin. 2-years follow-up results are associated with significant pain-relief, improved mobility, less intensive decongestive therapy, and a decreased edema-induced volume excess that are synonymous with an improved quality of life.

\section{FM3.2}

\section{Distal deep vein thrombosis after endovenous treatment of varicose veins}

\section{R. Stieger, R. Clemens, V. Jacomella, B. Amann-Vesti, T. O. Meier (Zürich)}

Objective: Introduction: Deep vein thrombosis (DVT) is known as a rare complication of endovenous ablation of varicose veins. The incidence is about $1 \%$. Only few follow-up reports exist. The aim of the study was to characterize distinct localisations of DVTs after endovenous laser ablation (EVLA) and ultrasound-guided foam sclerotherapy (UGFS) of varicose veins.

Methods: Methods: Retrospective analysis of consecutive patients undergoing EVLA with a 1470nm radial laser system for incompetent truncal vein insufficiency and / or UGFS with $1 \%$ polidocanol foam for tributary varicose veins. Stockings and low weight molecular heparin (LWMH) in prophylactic dose were post-procedural standard. The deep venous system was examined by duplex 
ultrasound 7-10 days and six months after the intervention. DVT treatment consisted of compression stockings and LWMH in therapeutic dose for 2 to 4 weeks.

Results: Results: Between January 2011 and May 2014576 legs were treated, 324 legs by EVLA and concomitant UGFS, 252 by UGFS alone. The median volume of foam used per treatment session was $8 \mathrm{ml}$ (range 3-16ml). The incidence of deep vein thrombosis (DVT) was $2.6 \%$ (15 cases). $73 \%$ of DVTs were located in a posterior tibial vein. There were no cases of proximal DVT or symptomatic pulmonary embolism. All except one DVT were asymptomatic. $86.6 \%$ of the thrombosis occurred in the combined (EVLA plus UGFS) treatment group. After 6 months all DVT were resolved completely. Conclusion: Conclusions: DVT after combined thermal and chemical endovenous ablation of varicose veins seems to be more frequent than described in the literature. Especially the posterior tibial veins are affected. Based on the course of DVTs in our cohort without proximal progression and the lack of symptoms it seems to be a benign complication. Duplex ultrasound not only of proximal but also of distal veins is mandatory to detect this complication.

\section{FM3.3}

\section{Diagnostic accuracy of fluorescence microlymphography for detecting lymphedema}

H. K. Keo ${ }^{l}$, S. G. Gretener ${ }^{2}$, E. G. Groechenig ${ }^{1}$, T. W. Willenberg ${ }^{3}$, M. Husmann ${ }^{4}$ ('Aarau, ${ }^{2}$ Langenthal, ${ }^{3}$ Bern, ${ }^{4}$ Zurich)

Objective: Fluorescence microlymphography (FML) is a minimally invasive technique for visualization of the cutanoues lymphatic network. A cutoff level of $12 \mathrm{~mm}$ spreading of the fluorescencent dye has been suggested for lymphedema. However, data on sensitivity and specificity are scarce and potential side effects not reported. The aim of the study was to assess the accuracy and of FML in unilateral lymphedema patients.

Methods: Lymphedema patients with unilateral leg swelling were assessed and compared with unaffected contralalteral limb. FML was performed in all affected index legs and the contralateral leg. At the most swollen part of the leg a $0.1 \mathrm{ml}$ FITC-labeled dextran (fluorescein isothiocyanate) was injected intradermally on both side at the same level. The spread of the dye in the lymphatic capillaries was measured in all dimensions and the maximum value was used for statistical analysis. The unaffected contralateral leg was used as control. Test accuracy and receiver operator characteristic (ROC) analysis was performed to assess possible threshold values that best predict lymphedema

Results: Between March 2008 and February 2014 a total of 70 patients with unilateral chronic leg swelling were clinically diagnosed with lymphedema. Median age was 45 (IQR 27, 56) years. Of those $46(65.7 \%)$ were female and $71.4 \%$ had primary lymphedema. The sensitivity, specificity, positive and negative likelihood ratio and positive and negative predictive value were 94.3\%, 78.6\%, 4.40, 0.07, $81.5 \%$ and $93.2 \%$ for the $12 \mathrm{~mm}$ cutoff level and $91.4 \%, 85.7 \%, 6.40,0.10,86.5 \%$ and $90.9 \%$ for the $14 \mathrm{~mm}$ cutoff level, respectively. The area under the ROC curve was 0.89 (95\% CI: 0.83, 0.95). No major adverse events were observed.

Conclusion: In conclusion, FML is an atraumatic and safe technique for detecting lymphedema in patients with leg swelling. The diagnostic accuracy seems to be best with a cut-off level of $14 \mathrm{~mm}$ maximum spread. 
FM3.4

\section{Veröden und punktweise Kleben: Eine neue Strategie der interventionellen Phlebologie.}

\section{J. C. Ragg (Berlin, München, Zürich)}

Objective: Die heutigen thermookklusiven Techniken und ebenso Schaumverödungen oder ClariVein ${ }^{\circledR}$ haben den Nachteil, dass die Regression der behandelten Venen nur allmählich und oft trotz Kompressionsmittel symptomatisch erfolgt (entzündliche Verödungsreaktion, Verfärbungen, Verhärtungen). Dieses Problem lösen Klebetechniken zumindest theoretisch, da sie die Venenwände sofort miteinander verbinden und das Lumen minimieren. Allerdings wird dieser Vorteil derzeit durch umfangreiche und kaum resorbierbare Acryl - Implantate zum fünffachen Preis einer Radiowellensonde erkauft (VenaSeal $\left.{ }^{\circledR}\right)$. In einer präklinischen Studie wurde versucht, eine Endotheldenaturierung durch Katheter - Schaumverödung mit punktförmigen Verklebungen zur initialen und permanenten Lumenreduktion zu kombinieren.

Methods: 32 zur Mini-Phlebektomie vorgesehene Venensegmente von $10-20 \mathrm{~cm}$ Länge und 6 - 12 mm Durchmesser (MW: 8,8) wurden in situ an einer Seite mit Ligatur und Mikrokatheter versehen und an der anderen Seite mit einer Schleuse. Über ein koaxiales Doppelkathetersystem (ScleroGlue) erfolgte zunächst eine Schaumverödung (Aethoxysklerol 1\%) und anschliessend nach Schaumabsaugung im Unterdruck eine punktweise Verklebung der kollabierten Vene ohne äusseren Druck mit verschiedenen Acrylatklebern im Abstand von mindestens $5 \mathrm{~cm}$. Nach Entfernung wurden die Proben histologisch untersucht.

Results: In 29/32 Venensegmenten fand sich eine totale Endotheldenaturierung, während in 3/32 Segmenten eine Denaturierung von 93 - 99\% vorlag. Die Verklebung war in 72/81 Klebestellen (88\%) technisch erfolgreich mit fester Verbindung der Venenwände. Der Verbrauch an Kleber betrug 3 - $6 \mathrm{mg}$ (MW: 4,8 mg) pro cm Venenstrecke.

Conclusion: Die ScleroGlue - Methodik scheint trotz Einsparungen des Klebematerials von 80 - 90\% sofortige und dauerhafte Reduktionen des Venendurchmessers zu ermöglichen. Die Bestimmung der in vivo erzielbaren Verschlussqualität ist Gegenstand einer 10/2014 beginnenden Studie.

\section{FM3.5}

Maladie veineuse chronique sur anomalie de drainage veineux intraosseux : perforante osseuse?

A.-A. Ramelet ${ }^{1}$, V. Crebassa ${ }^{2}$, C. D'Alotto ${ }^{3}$, G. Buero ${ }^{3}$, J.-L. Gillet ${ }^{4}$, A. Grenot-Mercier ${ }^{5}$, S. Küpfer ${ }^{6}$, E. Mendoza ${ }^{7}$, J.-M. Monsallier ${ }^{8}$, A. Obermayer ${ }^{9}$, K.-G. Pacheco ${ }^{10}$, N. Pros ${ }^{11}$, D. Soulie ${ }^{12}$ ( ${ }^{1}$ Lausanne, $^{2}$ ${ }^{2}$ Montpellier, ${ }^{3}$ Buenos Aires, ${ }^{4}$ Bourgoin-Jallieu, ${ }^{5}$ Arras, ${ }^{6}$ Bad Ragaz, ${ }^{7}$ Wunstorf, ${ }^{8}$ Alençon, ${ }^{9}$ Melk, ${ }^{10}$ Madureira, ${ }^{11}$ Toulouse, ${ }^{12}$ Melun)

Objective: 13 cas d'insuffisance veineuse des membres inférieurs consécutive à une anomalie de drainage veineux intraosseux ont été rapportés dans la littérature. Nous en avons présenté 2 nouveaux cas à la Sté Française de Phlébologie à Paris en décembre 2013 (Phlébologie. 2014;67:78-80), souhaitant en collecter davantage pour mieux définir cette entité largement méconnue et proposons de la dénommer «perforante osseuse ».

Methods: Après cette communication, la Sté Française de Phlébologie a lancé un appel à l'annonce de nouveaux cas. Ces derniers devaient être bien documentés, tant sur le plan de l'anamnèse que sur les investigations (écho-Doppler couleur au minimum, radiographie du tibia).

Results: 12 phlébologues (Allemagne 1, Argentine 1, Autriche 1, Brésil 1, France 6, Suisse 2) présentent 21 cas additionnels de perforantes osseuses originant du tibia (13 femmes, 8 hommes, âge moyen de 53 ans (32-79)), parfois bilatérales (3/21), nourrissant des varices « suspendues » au tiers inférieur de la jambe, symptomatiques (19/21), se compliquant de troubles trophiques chez 3 patients. 
Les antécédents traumatiques sont rares $(5 / 21)$ et il n'y a pas d'autre atteinte veineuse (saphènes, perforantes...) dans 15 cas. Le reflux de la perforante osseuse est toujours démontré au duplex, comme la présence d'une lacune osseuse et d'un sillon vertical « en rail de chemin de fer » dans 8 radiographies. Contrairement aux cas rapportés antérieurement, la majorité des 21 cas a été traitée par une ou plusieurs séances de sclérothérapie (16 cas), avec de bons résultats, sans complications majeures (douleurs dans 2 cas).

Conclusion: Le clinicien doit rechercher cette anomalie méconnue lorsque des varices jambières isolées ne s'expliquent pas par un reflux saphène ou de perforante. Nous suggérons le terme de « perforante osseuse », plus logique que celui d'anomalie de drainage veineux intraosseux.

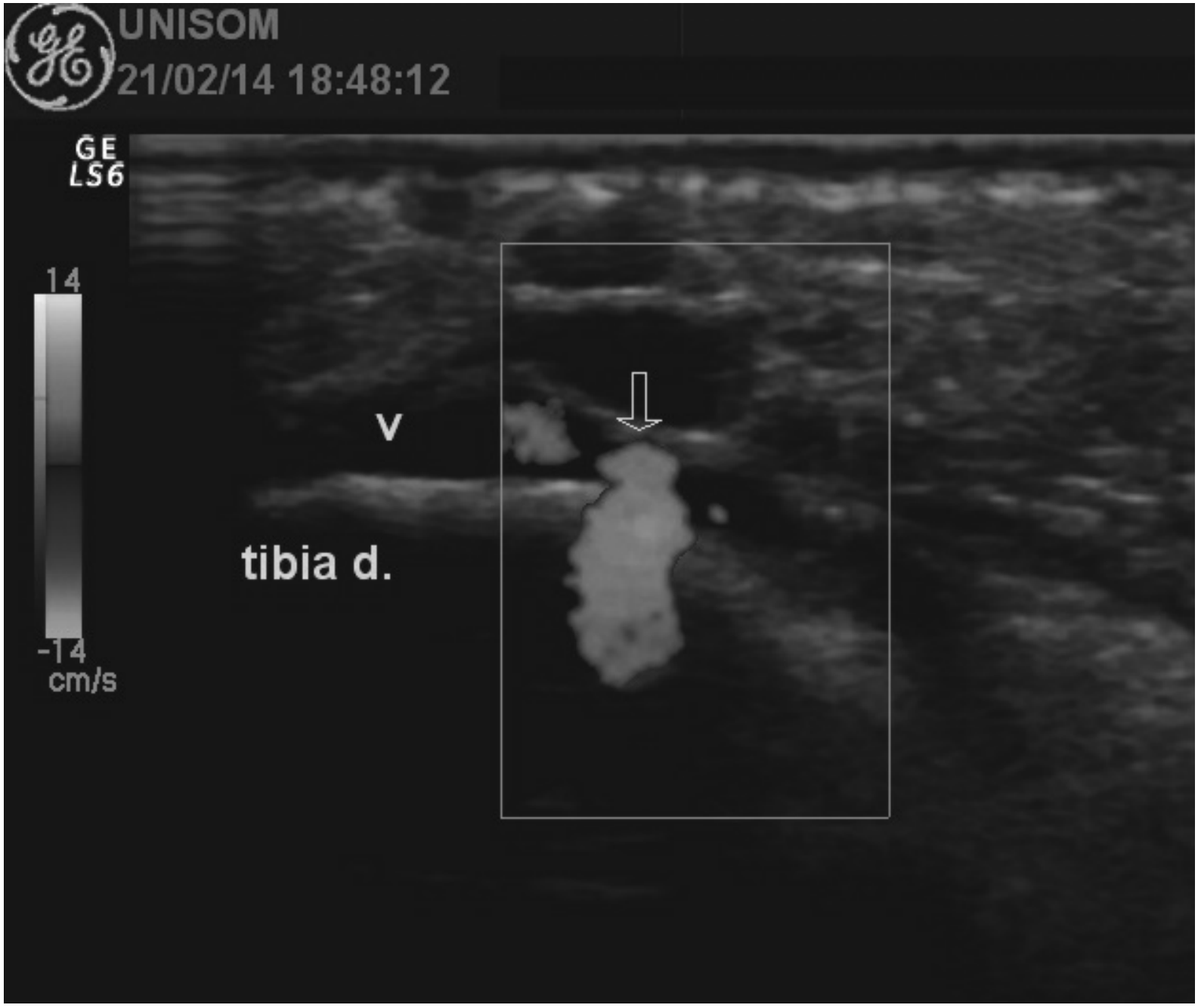

\section{FM3.6}

Chirurgische Therapie der akuten Becken-Bein-Venenthrombose: effektiv und sinnvoll

\section{S. Ockert, A. Leiser, J. Duwe, R. Seelos (Luzern)}

Objective: In $25-80 \%$ der Fälle bildet sich nach ilio-femoraler Thrombose ein postthrombotisches Syndrom (PTS) aus. Die operative Thrombektomie stellt eine unterschätzte Behandlungsalternative zur konservativen/interventionellen Therapie dar. Ziel der vorliegenden Untersuchung ist die Analyse perioperativer sowie mittelfristiger Ergebnisse nach offen chirurgischer Revaskularisation am eigenen Krankengut.

Methods: In die retrospektive Untersuchung wurden konsekutiv alle Patienten mit operativer Versorgung einer TVT eingeschlossen. Nach duplexsonogr. Nachweis wurde zusätzlich zur 
Ursachenabklärung und Ausschluss einer Lungenembolie eine CT Angiographie durchgeführt. Alle Patienten wurden im OP transfemoral in ITN thrombektomiert. Bei Bedarf erfolgte intraoperativ eine simultane Stentimplantation. Postoperativ und im Rahmen des Follow-up erfolgten regelmässig duplexsonogr. Kontrollen.

Results: In einem Zeitraum von 1/2008-5/2014 (6,5 Jahre) wurden insgesamt 15 Patienten offen chirurgisch bei akuter TVT thrombektomiert. Das Durchschnittsalter lag bei 37.3 Jahren. Die Mehrzahl der Patienten war weiblich (73,3\%). In allen Fällen konnte eine komplette Rekanalisation der Becken-Bein Strombahn erreicht werden (technischer Erfolg 100\%). In 33\% der Fälle erfolgte eine simultane Stentangioplastie. Die 30 D-Mortalität lag bei 0. Es erfolgte bei 2 Patienten im Rahmen des stationären Aufenthaltes eine Re-Operation (1x femorale Nachblutung; 1x Frühverschluss). Im Rahmen des Follow up (30 Monate) verstarb eine Patientin an einer Tumorerkrankung, bei einer Patientin erfolgte nach primärer Stenteinlage ein Endorepair bei Stenosebildung. Es zeigte sich lediglich bei einem Patienten ein lokales Rezidiv, ansonsten war bei allen Patienten das tiefe Venensystem im Rahmen des FU frei durchgängig.

Conclusion: Die offen chirurgische Rekanalisation stellt eine effektive und sichere Behandlungsmethode der frischen Becken-Beinvenenthrombose im perioperativen und mittelfristigen Verlauf dar. Wichtig bei der Indikationsstellung ist die Unterscheidung von frischen Thrombosen gegenüber für die Operation ungeeigneten subakuten/chronischen Verschlüssen. In Anbetracht relevanter Langzeitfolgen sollte aufgrund des niedrigen perioperativen Risikos im frischen Stadium der Thrombose eine operative Therapie, insbesondere bei jungen Patienten, der konservativen Behandlung vorgezogen werden. 


\section{Poster}

\section{Venöse und lymphatische Erkrankungen Pathologies lymphatiques et veineuses}

\section{P1}

\section{Interventionelle extraluminale Valvuloplastie mittels Hyaluronsäure - Gel}

\section{J. C. Ragg (Zürich)}

Objective: Für die Stammveneninsuffizienz gibt es außer den unbeliebten externen Kompressionsmitteln kaum ein Angebot an venen- bzw. kontinuitätserhaltenden Therapien: Die chirurgische extraluminale Valvuloplastie ist mit einem erheblichen Eingriff verbunden, die Fallselektion unklar und das Ergebnis nicht korrigierbar. CHIVA opfert ein Stück Vene und hat häufige Rezidive. Eine endoluminale Laser - Valvuloplastie ist nach ersten Erkenntnissen möglich, jedoch potentiell endothelschädlich. Könnte es möglich sein, insuffiziente Klappenzonen mittels perivenöser Injektion von Hyaluronsäure - Gel so zu formen, dass eine Restitution der Klappen mit orthogradem Fluss resultiert?

Methods: In einer Untersuchung an 20 Patienten (12w, $8 \mathrm{~m} ; 38$ - $67 \mathrm{~J}$.$) mit proximaler$ Stammveneninsuffizienz (VSM, Durchmesser 7,0 - 11,4 mm, Segmentlänge $4-8 \mathrm{~cm}$, HACH II) wurde ein 2\% NASHA - Gel mit einem Quervernetzungsgrad von $2 \%$ zur Verringerung des Lumens verwendet. Die Applikation erfolgte mit Sicherheits - Koaxialkanülen mit flexiblem Außenkatheter (IntraShape ${ }^{\circledR}$ ). Das Gel wurde perivenös unter Ultraschallsicht konzentrisch eingebracht und im Stehen so dosiert, bis eine Refluxelimination unter Valsalva - Belastung resultierte. Auf externe Kompressionsmittel wurde verzichtet. Kontrollen erfolgten bisher nach 2, 12 und 26 Wochen.

Results: Die Wiederherstellung eines orthograden Flusses gelang in 19/20 Fällen (95\%) mit Gelvolumina von 14 - $35 \mathrm{ml}$ (MW: 21,3 ml). Nach 12 Wochen war in 18/19 Fällen (83,3\%), nach 26 Wochen noch in 15/19 Fällen $(78,95 \%)$ ein orthograder Fluss festzustellen. Es wurden keine unerwünschten Nebenwirkungen beobachtet.

Conclusion: Die perivenöse Gel-Injektion ist eine sichere und kurzfristig effektive Modalität zur Wiederherstellung der Funktion von Stammvenen in frühen Stadien. Noch unklar ist, ob die Eignung nur insuffiziente, aber strukturell erhaltene Klappen betrifft, oder ob die Querschnittsreduktion bereits als solche hämodynamisch günstig ist. Injektionstechnik und Gele bedürfen weiterer Optimierung, um präzisere Depots mit weniger Materialeinsatz und längerer Wirkung herzustellen. Der Nachteil des langfristigen Wirkungsverlustes könnte durch gelegentliche Ergänzungsinjektionen ausgeglichen werden. Die bekannte Fähigkeit der Venen, unter Entlastung ihren Durchmesser zu normalisieren, lässt auf längere symptomfreie Intervalle hoffen als bei der Faltenbehandlung.

\section{P2}

Venenregression: Vergleich von ELVeS ${ }^{\circledR} 2-R$, Closure fast ${ }^{\circledR}$ sowie Verödungstechniken in einer neuen Scan-Methodik

\section{J. C. Ragg (Zürich)}

Objective: In der Behandlung von Stammvenen und Varizen mit modernen Kathetertechniken stellt die Venenregression (Querschnittsverminderung pro Zeit) ein wichtiges Qualitätskriterium dar. Je eher eine erkrankte Vene verschlossen, nicht mehr zu sehen und nicht zu spüren ist, desto besser ist die 
Therapie. Wie kann die Venenregression messtechnisch hinreichend genau und zugleich zeitsparend erfasst werden? Hierzu wird ein standardisierter manueller Ultraschall - Volumenscan evaluiert.

Methods: In einer prospektiven Analyse von randomisierten Eingriffen an Stammvenen von 10 - 15 mm Durchmesser an 32 Patienten ( $22 \mathrm{w}, 10 \mathrm{~m}, 22$ - 73 J.) mittels ELVeS ${ }^{\circledR}$ 2-R/1470 nm, Closure fast ${ }^{\circledR}$, Laser $810 \mathrm{~nm}$ single fiber ball tip sowie PhleboCath ${ }^{\circledR}$ - Schaumkatheter $($ je $n=10)$ wurden jeweils $20 \mathrm{~cm}$ - Segmente mit einem Linearschallkopf $(7-10 \mathrm{MHz})$ manuell mit 5 oder $10 \mathrm{~cm} / \mathrm{s}$ gescannt, um reproduzierbare Volumenaufzeichnungen $\mathrm{zu}$ erhalten. Postinterventionell wurden Kompressionsstrümpfen Kkl. 2 für 4 Wochen verordnet. Die Untersuchungen erfolgten vor und nach Therapie, nach 1 und 3 Tagen sowie nach 1, 2, 4 und 8 Wochen. Die Scans wurden retrospektiv ausgewertet.

Results: Die Sofortverschlussrate, ermittelt nach 15 min., betrug lediglich bei Verwendung des $810 \mathrm{~nm}$ Lasers $100 \%$ (10/10), während ELVeS® 2-R dies nur in 8/10 Fällen leistete, Closure fast ${ }^{\circledR}$ in $6 / 10$ und der Schaumkatheter nur in 2/10 Fällen. Obwohl bei allen Okklusionsverfahren eine sofortige Lumenreduktion angenommen wird, tritt diese in der Regel nicht ein. Bei einem Teil der Fälle war sogar eine vorübergehende Lumenzunahme der behandelten Vene um bis zu $21 \%$ zu beobachten: ELVeS® 2-R: 2/10, Closure fast ${ }^{\circledR}: 3 / 10$, Laser $810 \mathrm{~nm}$ : 1/10. Verödungsreaktionen konnten in allen Fällen dokumentiert werden, ihr Ausmass korrelierte jedoch nur in $62 \%$ d. F. mit klinischen Symptomen. Der Zeitbedarf für die Durchführung der Ultraschallscans betrug zwischen 0,5 und 1,1 min., MW: 0,68 min.

Conclusion: Mit dem vorgestellten einfachen Ultraschallscan werden mit wenig Zeitaufwand erhebliche Datenmengen gewonnen, deren Auswertung neue Details zu gängigen venösen Verschlusstechniken offenlegt und daher für künftige Vergleichsstudien oder Qualitätskontrollen besonders geeignet scheint, solange noch keine automatisierten 3D - Aufzeichnungen verfügbar sind. Keine der untersuchten Okklusionstechniken vermag die Kriterien Sofortverschluss, schnelle initiale Regression und Symptomfreiheit zufriedenstellend zu erfüllen.

\section{P3}

\section{Misdiagnosis of Plexiform Neurofibroma as Venous Malformation}

\section{R. Clemens ${ }^{1}$, A. Lillis ${ }^{2}$, J. Perez-Rossello ${ }^{2}$, R. Shaikh ${ }^{2}$, B. Amann-Vesti ${ }^{1}$, A. Alomari ${ }^{2}\left({ }^{1}\right.$ Zürich, ${ }^{2}$ Boston)}

Objective: The aim of this study was to identify Magnetic Resonance Imaging (MRI) characteristics that reliably distinguish deep plexiform neurofibroma (PNF) from venous malformations (VMs).

Methods: A database search over the past 14 years (1999-2013) was conducted for the keywords neurofibroma, plexiform neurofibroma and neurofibromatosis. Patients that were included in this study had clinically or histopathologically confirmed deep PNF, adequate MRI studies, and initial misdiagnosis as a vascular anomaly. The diagnoses of NF were confirmed by a medical geneticist. The imaging features of deep PNF recorded were: anatomical location, size, morphology, margins, signal intensity and post-contrast enhancement pattern. These findings were compared with those of classic spongiform VM with similar anatomical distribution. For these lesions the same features were recorded and analyzed (anatomical location, size, morphology, margins, signal intensity and postcontrast enhancement pattern.

Results: Ten patients with deep plexiform neurofibroma (PNF) were identified that were initially diagnosed with a vascular anomaly. Five patients had adequate imaging. These five patients were included in our study. There were 3 female and 2 male patients ranging in age from 10 months to 21 years. Deep PNFs were located in the cervicofacial region $(n=3)$, lower extremity $(n=1)$ and back/flank region $(n=1)$. The MRI features that distinguished VMs from deep PNFs were the serpiginous morphology, the target sign, relatively intermediate T-2 signal intensity and peculiar enhancement 
pattern without fluid-fluid levels or phleboliths and nerve root involvement. The target sign can be regularly found in PNFs, but may be also present in VMs and other vascular lesions.

Conclusion: Plexiform neurofibroma and venous malformation may overlap clinically and radiologically leading to misdiagnosis and potentially delayed management. The target sign does not distinguish these two entities. MRI features of plexiform neurofibromas which reliably distinguish them from venous malformation signs include the solid, serpiginous morphology, relatively intermediate T-2 signal intensity, and peculiar enhancement pattern without fluid-fluid levels, phleboliths or nerve root involvement. These findings may help to obviate the need of biopsy for diagnosing PNF.

\title{
P6
}

Exzentrische Kompression nach Verödungstherapie mit einem individuell geformten Silicon Gelpolster

\section{J. C. Ragg (Zürich)}

Objective: Die Rückbildung von Varizen nach Verödungstherapien kann optimiert werden, wenn die übliche konzentrische Kompression um eine fokale (exzentrische) Komponente ergänzt wird. Allerdings gab es hierfür bisher keine überzeugenden professionellen Lösungen. Wir berichten über die Evaluierung des Venartis ${ }^{\circledR}$ Silicone Gel Pad.

Methods: Das SGP besteht aus einer selbstklebenden Basisfolie, einem Silicon - Gel, welches strangartig exakt entlang des Varizenverlaufes aufgetragen wird und einer Deckfolie. Die Untersuchung umfasste 72 Patienten mit 88 oberflächlichen Varizen (Durchmesser 5,0 - 13,2 mm, MW 7,4 mm), die eine Schaumverödung (Aethoxysklerol 1 - 2\% + Luft, 1+4) erhielten. Die Varizen wurden randomisiert für eine 14 tägige Kompression mit Kompressionsstrumpf KKL 2 (A) zuzüglich SGP, oder (B) ohne SGP. Die Venendurchmesser wurden nach 2 und 8 Wochen mittels Ultraschall vermessen.

Results: Die Studiengruppe (A) zeigte eine Reduktion des Venendurchmessers von 65,8\% (31,2 $82,4 \%)$, gegenüber $39,4 \%(21,0-61,8 \%)$ in der Kontrollgruppe (B). Die Rate symptomatischer Verödungsreaktionen zeigte sich um 52\% reduziert, Verhärtungen um 58\% und Verfärbungen um 68\%. 4/72 Patienten entfernten den Siliconverband nach 5-12 Tagen wegen geringer Missempfindungen, alle diese Fälle betrafen die Kniekehle. Kleine Hautirritationen, die weder Komfortgefühl noch Tragezeit beeinflussten, wurden in 8/72 Fällen beobachtet (11,1\%). Andere unerwünschte Wirkungen oder Allergien traten nicht auf.

Conclusion: Venartis ${ }^{\circledR}$ SGP ist eine sichere und effektive Modalität zur Komfortsteigerung und Beschleunigung der Rückbildung oberflächlicher Varizen nach Schaumsklerosierung. In Folgestudien werden die optimalen Gel - Dosierungen und der optimale Kompressionsdruck des ultraschalltransparenten SGP zu ermitteln sein.

\section{P10}

Complex vascular malformations: overlapping and distinguishing features in Klippel-Trenaunay and Parkes-Weber syndrome

\author{
P. Köger, R. Clemens, T. Pfammatter, T. O. Meier, B. Amann-Vesti (Zürich)
}

Objective: Complex vascular syndromes are frequently misdiagnosed and therefore mistreated. Clinical, radiological and genetic features of capillary-lymphatic-venous malformations (CLVM), 
eponymously called Klippel-Trénaunay-Syndrome and Capillary malformation with arteriovenous fistulas (CAVF), also called Parkes-Weber-Syndrome, were compared to distinguish these two different entities to prevent misdiagnosis.

Methods: A chart review of patients with CLVM and CAVF seen at our clinic was conducted to describe overlapping and distinguishing features. Clinical and imaging features are compared.

Results: CLVM is a complex overgrowth disorder of slow-flow malformations (capillary, lymphatic, venous) in an overgrown limb. The capillary malformations are typically located on the lateral side of the limb in close relationship with the marginal vein. Underlying genetic causes (PIK3CA mutations) seem to be involved.

CAVF is characterized by capillary malformations and overgrowth of the affected extremity with diffuse hypervascularity leading to arteriovenous shunting on the capillary-muscular level. Although considered sporadic, RASA1 mutations seem causative. Even if CLVM and CAVF share common clinical features like capillary malformation and overgrowth, the marginal vein is in contrast to CLVM rarely found in CAVF. Arteriovenous shunting is not found in CLVM. Lymphatic malformations are usually not seen in CAVF.

Conclusion: The wrong triple eponym "Klippel-Trenaunay-Weber"-syndrome is regularly found in referral letters or in scientific literature creating nosologic uncertainty. Despite overlapping clinical features, CLVM and CAVL are different entities. CLVM only has slow-flow vascular malformations, while CAVF is considered a high-flow lesion. Conducting accurate analyses of the specific clinical patterns and imaging findings of vascular anomalies and using proper terminology is the key to diagnosis and appropriate clinical management of vascular anomalies. Interventional treatment is profoundly different as veins in CLVM can be treated with endovenous laser or sclerotherapy whereas the treatment in arteriovenous shunting in CAVF is transarterial embolization.

\section{P12}

\section{Shortness of breath after EVLT, a word of caution}

\section{Ch. Jeanneret ${ }^{1}$, S. Brunner ${ }^{2}$, M. Bieli ${ }^{2}\left({ }^{1}\right.$ Bruderholz, ${ }^{2}$ Basel)}

Objective: We present a 64 year old patient, who was admitted to the hospital because of progressive exercise induced shortness of breath since one week. Four weeks earlier endovenous laser therapy was performed on his right great saphenous vein.

Methods: The duplexsonographie control after the intervention showed a level 3 thrombus according to the classification system of Lawrence et al. Thrombosis prophylaxis was implemented for 10 days together with compression stockings of the calf. The medical history was uneventful, no thromboembolic events were reported in first degree relatives.

At admission we found a male patient with no swelling, erythema or pain of the right leg.

Results: Labaratory tests: The D-dimer and CRP-level were significantly elevated $(4.47 \mathrm{mcg} / \mathrm{ml}$ and $100 \mathrm{mg} / \mathrm{ml}$ respectively).

CT scan of the lung showed central and paracentral pulmonary embolism.

In the Duplexultrasonography we found an occluded great saphenous vein on the right side in the treated region with a thrombus expanding through the sapheno-femoral junction into the common femoral vein.

The patient was treated with Phenprocoumon (initially in addition with Dalteparin) and could be discharged after four days of hospital stay.

Conclusion: The EVLT is a very elegant and rapidly expanding method of treatment of varicose veins. 
Because of the minimally invasive character of the procedure and the excellent technique success rates the method is increasingly requested by patients. Studies have shown the safety of the method. Until now there are only few reports of DVT and even lesser of pulmonary embolism.

Our case shows that despite all this precautions there remains a substantial risk of developing a potentally lethal complication. The closure level 3 after treatment might need LMWH in therapeutic dosis and further controls of follow up after 1 week.

\section{P15}

\section{Eine ungewöhnliche Ursache von Lungenembolien}

\section{A. Baumer ${ }^{1}$, A. Habersaat ${ }^{1}$, J. Schmidli ${ }^{2}$, U. Benecke ${ }^{1}$, M. Beckmann ${ }^{l}\left({ }^{l}\right.$ St. Gallen, ${ }^{2}$ Bern $)$}

Objective: Fallbericht eines 46 jährigen Patienten

Case: Bei einem 46 jährigen Patienten wurden aufgrund von atemabhängigen Thoraxschmerzen computertomographisch segmentale und subsegmentale Lungenembolien in den Lungenunterlappen beidseits nachgewiesen. Bei fehlenden Beschwerden im Bereich der Beine ergab eine Duplexsonographie keine Hinweise für eine Thrombose oder postthrombotische Veränderungen in den Beinvenen. Im Rahmen einer Abdomensonographie fiel jedoch eine aneurysmatisch erweiterte, teilthrombosierte V. iliaca externa rechts auf. Zur Planung des weiteren Vorgehens wurde eine MRPhlebographie durchgeführt, welche das gut $6 \mathrm{~cm}$ grosse Aneurysma bestätigte. Zur Prophylaxe weiterer Embolisationen aus dem venösen Aneurysma und um eine Dauerantikoagulation bei diesem jungen Patienten zu vermeiden wurde entschieden, eine primär venenerhaltende operative Sanierung anzustreben. Diese konnte mittels einer dorsalen Venorraphie und einer ventralen Venenpatchplastik mit der doppelt angelegten V. iliaca communis durch eine Lumbotomie rechts durchgeführt werden. Die Histopathologie wies bei gestörtem Verhältnis der Skleroproteine mit herdförmigem Schwund der glatten Muskulatur auf eine kongenitale Ätiologie des venösen Aneurysmas hin. Drei Monate nach dem Eingriff konnte bei duplexsonographisch unauffälligem venösem Abfluss im rechten Becken die orale Antikoagulation gestoppt werden. Der Patient ist seither beschwerdefrei.

Conclusion: Venöse Aneurysmata sind selten, insbesondere im Bereich der Beckenvenen. Soweit uns bekannt wurden erst 10 Fälle iliacaler venöser Aneurysmata in der englischen Literatur beschrieben. Die ersten venösen Aneurysmata wurden 1968, die meisten in der V. jugularis interna, V. saphena magna, V. cava inferior, V. femoralis superficialis und V. poplitea beschrieben. Sie werden als persistierende lokale Erweiterung des Gefässlumens auf das zwei- bis dreifache definiert. Die Pathogenese ist unklar, neben lokalen Wandschädigungen durch Trauma und Entzündung wird vor allem ein kongenitaler oder degenerativer Verlust des Bindegewebes diskutiert.

Bei allen pulmonalen Embolien unklare Genese, sollte auch an ein venöses Aneurysma als Emboliequelle gedacht werden.

Die venenerhaltende Aneurysmaresektion mit Venorraphie ist eine gute Option zur operativen Ausschaltung venöser Aneurysmata.

\section{P16}

\section{„Shoe lace injury“ following varicose vein treatment}

\section{W. Mouton, S.-L. Hool (Thun)}

Objective: Nerve injuries unfortunately do occur as complications of varicose vein surgery or endovenous vein ablations. 
We present an injury of the medial branch of the superficial peroneal nerve as a case report.

Methods: A 60 year old femal patient presented with ankle oedema and perimalleolar skin changes due to a left short saphenous vein insufficiency and right perforating vein insufficiency ( $\mathrm{C} 4$ according the CEAP classification). Cardiovascular risk factors were a positive family history and obesity (BMI $34 \mathrm{~kg} / \mathrm{m} 2$ ). In duplex sonography the deep venous system was found to be sufficient but the left short saphenous vein and a relevant right medial calf perforator were found to be insufficient.

The procedure was performed under spinal anaesthesia. The patient was positioned on the abdomen. A left short saphenous vein high ligation and stripping was performed as well as a right perforator ligation and stab avulsions of the side branches on both legs. There were no stab avulsions on the dorsum of the feet and the varicose side branches were localised on the dorsal sides of the legs.

Results: As the patient lives in an alpine valley she wished to stay over night. During the night she had the feeling that the bandage was too tight but did not bother to disturb the nurse.

When the bandage was changed the next morning the patient complained of numbness on the dorsal aspect of the first three toes on both sides.

Clinically and later confirmed by neurological examination the deficit corresponded to an injury of the medial branches of the superficial peroneal nerve. There was no indication that the injury was caused by spinal anaesthesia,surgery or retractors. Until proven otherwise the nerve trauma was caused by the bandage applied with too much pressure - this type of nerve trauma is normally seen when (hiking) shoe laces are too tight. The neurological recovery was complete on the right side, on the left side it is now - 15 months after surgery - nearly complete. The patient feels no limitations due to the left-sided minimal neurological rest deficit.

Conclusion: An injury to the medial branches of the superficial peroneal nerve following varicose vein surgery is very rare and can be caused by the bandage.

When patients complain about tight bandage or numbness - following varicose vein surgery or endovenous vein ablation - this should be taken seriously and the bandage immediately loosened.

\section{P21}

Iliaco-caval stenting for lower limb venous congestion syndrome caused by breast cancer-associated retroperitoneal desmoplastic fibrosis

\section{B. Spahic, R. Pfiffner, B. A. Baettig, B. Amann-Vesti, T. Pfammatter, M. Husmann (Zürich)}

Objective: Retroperitoneal fibrosis may cause compression of the iliacocaval venous tree and result in lower limb edema.

Case: We present the case of a $55 \mathrm{yr}$ old female patient with long-term ( $>10 \mathrm{yrs})$ metastatic breast cancer including retroperitoneal metastasis that were well controlled with anticancer treatment.

Here previous history included multiple chemotherapies and radiotherapy for metastasis of in the right femur, venous thrombosis and stenting of a high grade stenosis of the external iliac vein. Her current medication was rivaroxaban $20 \mathrm{mg}$ and paclitaxel under which she was doing well except for some long-term mild edema of the right leg, that was treated with compression therapy.

She presented with a sudden onset of massive edema of both lower limbs which limited her ambulatory walking capacity to only 20 meters. CT-scan ruled out retroperitoneal tumor growth or venous compression by tumor mass but showed retroperitoneal desmoplastic fibrosis with compression of the iliac-ocaval veins and iliac instent-thrombosis.

Via a left femoral access a cross-over thrombolysis with 10mg rt-PA was performed. The follow-up phlebography showed a patent stent in the external iliac vein with partial wall thrombus in the femoroiliac segment. Venous outflow of both limbs remained severely impaired. Therefore, one Wallstent 16/90 mm (Boston Scientific Corp., Natrick, MA, USA) was implanted into the inferior caval vein and a second one $(14 / 60 \mathrm{~mm})$ into left the common iliac vein. Final phlebography proved iliaco-caval 
decompression by the two Wallstents followed by clinical improvement of the swelling and ambulation capacity. Anticoagulation was $2 \times 15 \mathrm{mg}$ rivaroxaban daily for 21 days, and then set on 20mg daily.

Follow-up showed a sustained clinical improvement of the left leg and a similar situation on the right leg as previous to the venous decompensation.

Conclusion: Retroperitoneal desmoplastic fibrosis with iliaco-caval venous compression causing decompensation of preexisting lymphedema can be successfully treated with venous iliaca-caval stenting improving both edema regression and walking capacity.

\section{Periphere arterielle Gefässe und Methoden Vaisseaux artérielles périphériques et méthodes}

\section{P5}

\section{Die intermittierende pneumatische Kompressionstherapie ArtAssist bei komplexer AVK}

\section{R. Kaiser (St. Gallen)}

Objective: Bei der komplexen AVK und bei Verschluss komplexer Rekonstruktionen wie femorocruralen Bypässen gilt es mit allen Massnahmen den drohenden Extremitätenverlust zu vermeiden oder zu verzögern und eine invalidisierende Gehstreckenlimitierung zu verbessern. Zur Stimulation der positiven vasotropen Faktoren ist eine Modulation des Blutflusses zu erreichen.

Methods: Die intermittierende pneumatische Kompressionstherapie ArtAssist wurde als Nebeneffekt der maschinellen venösen Kompressionstherapie entdeckt und wird seit 2006 bei uns eingesetzt. Es wird dabei über ein Manschettensystem im Unterschenkelbereich ein kurzzeitiger zentripetaler Druck von $120 \mathrm{~mm}$ HG über $3 \mathrm{sec}$. aufgebaut mit anschliessender Erholungsphase von $17 \mathrm{sec}$, die Anwendung erfolgt im Sitzen. Durch die Entleerung des Venensystems sinkt der Venendruck und damit der Druck in der Endstombahn zu Gunsten des arteriellen Einstromes. Die Anwendung erfolgt in vorzugsweise halb- bis einstündigen $3 x$ täglichen Intervallen. Untersucht wurden 42 Patienten mit AVK III und IIb mit einer Gehstrecke von wenigen Metern sowie AVK IV a ohne akute Amputationsgefahr. Folgende Kriterien : keine akute Amputationsgefahr, kein florider Infekt, keine Oedem, keine Herzinsuffizienz, komplexe Gefässsituation, Patienten- und Umfeldcompliance positiv, Sicherheitsnetz mit regelmässigen klinischen Kontrollen und Duplexsonografie in fixen Intervallen. Kontrolliert wurden die Rekapillarisation, das subjektive Befinden und die Stabilität der Kollateralperfusion im Duplex.

Results: Es gelang $75 \%$ der Extremitäten zu erhalten, was mit den bekannten Studienwerten von 86 $\%$ mit und $32 \%$ ohne ArtAssist korrespondiert. Das Kriterium war dabei eine Verhinderung einer Progression. Entscheidend war die Rückführung der Ruheschmerzen und die positive Entwicklung der freien Gehstrecke. Eine Verbesserung des in der Regel postocclusiven Index konnte nicht dokumentiert werden, ein Nachweis der Konstanz der peripheren postocclusiven Flussmusters konnte dargestellt werden.

Conclusion: Zum Extremitätenerhalt ist diese adjuvante aktive Methode bei komplexer AVK unter Berücksichtigung klarer Kriterien eine sinnvolle Massnahme.

Durch den Sogeffekt wird der erniedrigte arterielle Einstrom begünstig und vasotrope Faktoren 


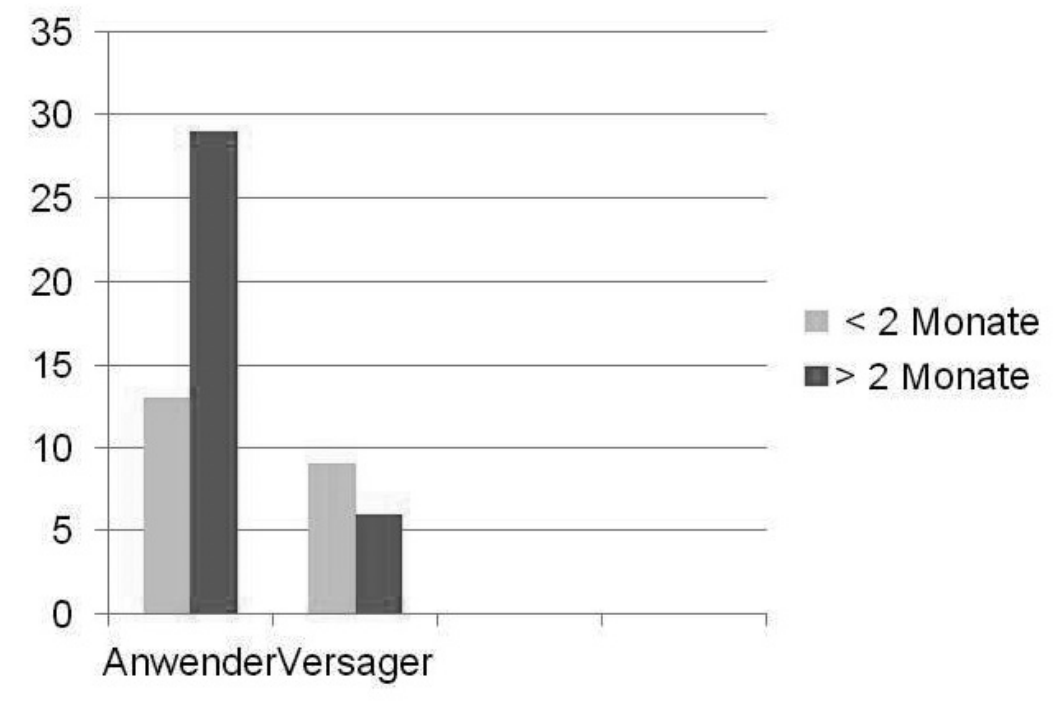

P8

Long Term Follow-up after Endovascular Brachytherapy of Femoro-popliteal Arteries

C. Thalhammer, E. Alvarez, V. Jacomella, M. Husmann, B. Amann-Vesti (Zürich)

Objective: To perform a long term follow-up after endovascular brachytherapy (EVBT) or and plain balloon angioplasty regarding vessel patency and diameter. EVBT had been successfully used to decrease restenosis in the short term, but long term data are lacking.

Methods: Participants of a randomized study comparing EVBT and balloon angioplasty alone were invited for a follow-up examination ten years after intervention. Using a standardized ultrasound protocol measurement of the patency and vessel diameter was performed of the femoral and popliteal arteries and the ankle-brachial index was obtained.

Results: A total of 29 patients were included, 15 had been treated with EVBT group. Patency of the target lesion did not differ between the two groups ( $86.7 \%$ vs. $92.8 \%)$. Vessel diameter of the target lesion was significantly greater in the EVBT group $(6.8 \mathrm{~mm}$, range 3.9-9.9) compared to the control group $(4.9 \mathrm{~mm}$, range $3.2-7.4 ; \mathrm{p}=0.002)$. An arterial ectasia with a diameter greater than $8 \mathrm{~mm}$ was found in four patients of the EVBT group, but none in the angioplasty group.

Conclusion: Ten years after EVBT of the femoro-popliteal arteries the vessel diameter is significantly increased whereas patency rate is not different compared to angioplasty alone. Patients treated with EVBT should be controlled by duplex ultrasound to detect aneurysm formation.

\section{P9}

Endoluminal stent-graft relining of arterial bypass grafts for treatment of perigraft seromas in four consecutive patients.

L. Chaykovska ${ }^{l}$, G. D. Puippe ${ }^{l}$, M. Romero Toledo ${ }^{1}$, M. Glenck $^{l}$, Z. Rancic ${ }^{l}$, T. Pfammatter ${ }^{1}$, F. Veith ${ }^{2,3}$, R. Pfiffner ${ }^{1}$, D. Mayer ${ }^{1}$, M. Lachat ${ }^{l}\left({ }^{1}\right.$ Zürich, ${ }^{2}$ New York, ${ }^{3}$ Cleveland)

Objective: Surgical treatment of perigraft seroma (PGS) might require graft replacement and results might be disappointing. We describe a new less invasive method that consists in relining endoluminally the graft(s) incriminated with corresponding stentgraft(s).

Methods: Four consecutive patients presenting symptomatic perigraft seromas surrounding synthetic vascular graft (ePTFE, 2; Polyesther, 2) were treated by relining method covering most of the inner 
surface of the grafts with the implantation of self-expanding stentgrafts (Viabahn, Gore), generally oversized by $1 \mathrm{~mm}$. Three patients developed PGS of renovisceral bypass grafts (5- to $8 \mathrm{~mm}$ in diameter) and one patient developed PGS on a femoro-femoral cross-over bypass graft $(12 \mathrm{~mm}$ in diameter).

Results: In all cases symptoms cleared off and perigraft seroma size decreased significantly and/or disappeared during follow-up, as confirmed by CT angiography. No recurrence was diagnosed during maximal follow-up of 18 months.

Conclusion: PGS is a potentially harmful complication of bypass surgery using synthetic grafts. Relining with stentgrafts is a less invasive alternative to graft revision and/or replacement. In our limited series, this original technique showed to be safe and effective method, but more experience is required before it can be recommended in all cases.

\section{P13}

Acute effects of haemodialysis on central venous and arterial pressure characteristics

C. Thalhammer, S. Segerer, M. Augustoni, V. Jacomella, R. Clemens, B. Amann-Vesti, M. Husmann (Zürich)

Objective: Accurate determination of dry weight (DW) remains a challenge but is essential in patients on intermittent haemodialysis (HD) treatment to maintain optimal fluid status with respect to cardiac function and changes in central aortic pressure. We evaluated non-invasively changes in central arterial and venous pressures during dialysis.

Methods: Central venous pressures were derived by ultrasound-assisted silicon-based pressuremanometer at the contralateral cephalic vein during haemodialysis. Central aortic pressure changes were assessed as aortic augmentation index (AIx) and subendocardial viability ratio (SEVR) by radial applanation tonometry and brachial arterial blood pressure measurements. Bioimpendance was used to measure total body water (TBW), as well as extracellular (ECW) and intracellular (ICW) water before and after HD. All measurements were performed prior during and after one and two hours on HD except for bioimpedance that was only assessed before and after dialysis.

Results: Ten patients (5 female) were included with a median age of 72 years (23-82). Haemodialysis reduced the weight by $2.0 \mathrm{~kg}$, corresponding to a measured decrease in TBW of $1.9 \mathrm{~L}$ ( $36.1 \mathrm{~L}$ to 34.2 L, n.s.). The mean CVP showed a significant decrease $(9.0 \mathrm{cmH} 2 \mathrm{O}$ to $0.8 \mathrm{cmH} 2 \mathrm{O} ; \mathrm{p}=0.0005)$ during dialysis. The major and significant drop in CVP was found during the first hour of haemodialysis (9 $\mathrm{cmH} 2 \mathrm{O}$ to $2.8 \mathrm{cmH} 2 \mathrm{O}$ ). Starting and stopping dialysis was reflected by a reduction of $2.6 \mathrm{cmH} 2 \mathrm{O}$ and a rise of $2.8 \mathrm{cmH} 2 \mathrm{O}$ (n.s.). AIx decreased continuously from $26.1 \%$ to $21.0 \%$ (n.s.). SEVR increased significantly from $126 \%$ to $156 \%$ ( $\mathrm{p}<0.05$ ) during HD, and decreased to $139 \%$ direct after HD (n.s.).

Conclusion: Intermittent haemodialysis is associated with changes in central venous and arterial pressures and is easily feasible during haemodialysis by non-invasive assessments.

\section{P14}

Ist die Shift weg von der peripheren Rekonstruktion hin zur Intervention nachhaltig?

\section{R. Kaiser (St. Gallen)}

Objective: Sensibilisierung einer Shift weg von der peripheren Rekonstruktion hin zur Intervention. Erhalt der operativen rekonstrutiven Expertise. Fokussierung auf Erhalt der peripheren operativen Techniken im Sinne einer sinnvollen gefässchirurgischen Ausbildung. 
Methods: Retrospektive Anlayse der quantitativen Entwicklung peripheren Rekonstruktionen und Interventionen in den letzten 5 Jahren am Beispiel eines Zentrumspitals.

Results: Die Analyse der Daten ergab, dass sich die operativen Rekonstruktionen innerhalb der letzten 5 Jahre auf $25 \%$ des Ausgangswertes $(n=120)$ reduzierten und eine Shift zur peripheren Intervention erfolgte z.B. Stentgraft bei Poplitealanuerysma.

Conclusion: Durch den quantitativen Rückgang der operativen Rekonstruktionen besteht die Gefahr eines Expertiseverlustes, so dass die Operation dann als ultima ratio nicht mehr mit sehr guter Qualität erfolgen kann und die Amputationsrate in Folge des Misserfolges steigt. Eine interdisziplinäre Berücksichtigung und Refokussierung auf dieses vitale Bedürfnis muss ins Bewusstsein gerückt werden z.B. primäre operative Versorgung PAA oder Intervention AFS Verschluss unter Berücksichtigung der Begleiterkrankungen bzw. des AZ der Patienten.

\section{P17}

Endovascular repair of an acutely thrombosed popliteal aneurysm in a patient with calciphylaxis

\section{Luchsinger, M. Lachat, T. Pfammatter, J. Hafner, B. Amann-Vesti, M. Husmann (Zürich)}

Objective: Endovascular repair of popliteal aneurysms may be an alternative to open repair especially in patients with skin disease and potential risk of wound healing.

Case: We report the case of a 75 year old male patient with end-stage renal disease (KDOQI stage V on dialysis) presenting with acute limb ischemia (Rutherford $\mathrm{IIb}$ ) due to an occluded popliteal aneurysm $(5.5 \mathrm{~cm})$ and multiple, painful skin lesions at the calf. Assuming calciphylaxis, open repair was waived because of impending wound healing complications. Via an antegrade ipsilateral femoral access the completely occluded popliteal artery was probed with an 0.018 " wire (Control wire, Boston Scientific Corp., Natrick, MA, USA) and access to the only patent peroneal run-off gained. Two stentgrafts (Viabahn 6/150mm and 9/150mm, GORE Inc., Flagstaff, AZ, USA) were implanted into the popliteal and distal femoral arterial segments, and a self-expandable bare metal stent (Xpert 5/40mm, Abbott Vascular, Illinois, U.S.A) into the stenosed tibiperoneal trunc. Follow-up at three months proved an excluded popliteal aneurysm and a patent femoro-peroneal run-off. Calciphylaxis was subsequently confirmed by biopsy and improved on steroid therapy.

Conclusion: Stentgrafting of an acutely thrombosed popliteal aneurysm without use of pharmacomechanical therapy in patient unfit for surgery seems is feasible and showed to be safe. It might be considered as a bridging treatment until open repair is possible after elimination of transitory limiting factors for surgery.

\section{P19}

\section{Percutaneous suction embolectomy at the femoral bifurcation}

\section{Husmann, B. Amann-Vesti, T. Pfammatter, V. Jacomella (Zürich)}

Objective: To report the use of an endovascular technique for the treatment of acute embolic occlusion of the common femoral artery.

Case: An 82-year-old female presented with an acute limb ischemia because of an embolic occlusion of the common femoral artery. Following access preclosing with a percutaneous sutured-based closure system, percutaneous embolectomy of the common femoral artery was achieved with a 10 F-sheath only by means of side-port suction with a $50 \mathrm{ml}$ syringe. As the guidewire was left in place the clot- 
loaded sheath could be repeatedly retrieved, purged of the colts and reinserted until the embolectomy was complete.

Finally, haemostasis was achieved with the suture-mediated closure device.

Conclusion: Percutaneous suction embolectomy of the common femoral artery with a combination of suture-mediated access closure device and a large bore introducing sheath only, is feasible. This simple technique may be helpful especially for patient who are at high risk for surgery and have saddle emboli at the common femoral bifurcation.

\section{P20}

\section{Antoniusfeuer heute}

\section{Reutter, J. Lindenberg, M. Husmann, T. Pfammatter, B. Amann-Vesti (Zürich)}

Objective: Der verbreitete Konsum illegaler Drogen und Medikamentenmissbrauch führt zum vermehrten Auftreten von schweren Ischämien bedingt durch Vasospasmen. Wir beschreiben zwei Patienten mit schwerer Extremitäten- und Organischämie.

Case: Ein 34-jähriger HIV positiver Patient stellte sich mit einer akuten kritischen Ischämie der linken Hand und beider Füsse sowie einer mittelschweren Niereninsuffizienz vor. Bildgebend zeigten sich glattwandige, sehr schmalkalibrige Gefässe ohne Hinweise für Dissektion oder Vaskulitis sowie eine Minderperfusion der rechten Niere. Ausser Nikotin- und Alkoholkonsum sowie der antiviralen Therapie mit Ritonavir wurde jegliche Drogen- oder Medikamenteneinnahme verneint. Peroral verabreichtes Nitroglycerin führte $\mathrm{zu}$ einer vorübergehenden Besserung. Unter therapeutischer Heparinisierung, Ilomedin i.v., Aspirin und Calciumantagonisten stellte sich innert Tagen praktisch eine Normalisierung der arteriellen Durchblutung und Nierenfunktion ein. Am Ende der Hospitalisation gab der Patient $\mathrm{zu}$, dass er wegen einem grippalen Infekt ein ergotaminhaltiges Medikament aus Paraguay eingenommen hatte. In der kürzlich erfolgten Nachkontrolle zeigten sich unverändert offene Gefässe.

Ein 39-jähriger Patient mit ausgeprägtem kardiovaskulärem Risikoprofil und St. n. cerebrovaskulärem Insult vor 3 Monaten bislang unklarer Genese, wurde wegen einer neu aufgetretenen PAVK Stadium III links zur PTA zugewiesen. Duplexsonographisch fanden sich Verschlüsse der Unterschenkelarterien. Angiographisch zeigten sich schwere Spasmen aller drei US-Arterien, welche nach intraarterieller Injektion von Nitroglycerin regredient waren. Noch während der Intervention waren die Fusspulse wieder palpabel. Nach einer mehrtägigen Ilomedin i.v. Therapie blieben die Gefässe offen. Erst nach mehrmaligem Nachfragen wurde der Konsum von Kokain und Marihuana zugegeben. Nachträglich muss angenommen werden, dass auch das cerebrovaskuläre Ereignis vasospastisch bedingt war.

Conclusion: Bei Extremitäten-und/oder Organischämie mit glattwandigen, schmalkalibrigen Gefässen ist an Drogen-oder Medikamenten induzierte Vasospasmen zu denken und rasch eine vasodilatierende Therapie einzuleiten. Die Wirkung von Ergotamin wird stark erhöht, und es ist deshalb kontraindiziert bei gleichzeitiger Einnahme von Inhibitoren des Cytochrom P450, CYP34 (z.B. Ritonavir, MacrolidAntibiotika). 


\section{Aorta und grosse Arterien \\ Aorte et grandes artères}

\section{P4}

A safe technique for percutaneous access of synthetic grafts for large sheath introduction in (T)EVAR

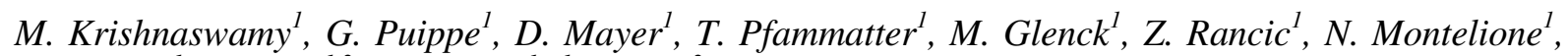
R. Pfiffner ${ }^{1}$, F. Veith ${ }^{1,2}$, M. Lachat ${ }^{1}\left({ }^{1}\right.$ Zürich, ${ }^{2}$ New York)

Objective: Percutaneous access for EndoVascular Aortic Repair (EVAR) has been showed to be advantageous alternative to open access. In percutaneous EVAR (PEVAR) the sheath is advanced inside the vessel lumen after preclosing system has been used. When vascular synthetic graft access has to be accessed by a large sheath however, open exposure, especially to avoid graft (anastomotic) disruption when advancing the sheath is used. We describe here an original technique that was successfully used for PEVAR in patients with synthetic vascular graft in the groin.

Methods: 10 consecutive patients with abdominal aortic aneurysm (AAA) and synthetic vascular graft in the groin were treated with PEVAR since 2011. Six first patients were treated with standard technique (preclosing and advancing the sheath inside the vessel lumen). In last four patients PTA balloon was used to predilate the synthetic vascular graft after preclosing was performed to reduce friction or allow friction-free advancement of the large size sheath. In latter patients, one required 20 Fr sheath and was treated with a $6 \mathrm{~mm}$ PTA balloon. In remaining patients 8mm Balloon and $24 \mathrm{Fr}$ sheath were used. Preclosing was performed using ProGlide (Abbott) in all cases.

Results: In all cases PEVAR was completed successfully. Graft disruption occurred in one of the patients where standard technique was used. This was corrected by reanastomosing the graft. Following this experience, PTA technique was successfully used in 4 last patients.

Conclusion: Main advantages of PEVAR are the shorter time for gaining vascular access, avoidance of wound healing disorder or infection and reduction of postoperative pains or groin discomfort. PEVAR with standard technique in patients with synthetical vascular graft in the groin is possible, but can lead to disruption of the distal anastomosis. Using predilation seems to overcome this issue without interfering with sealing quality of the preclosing system.

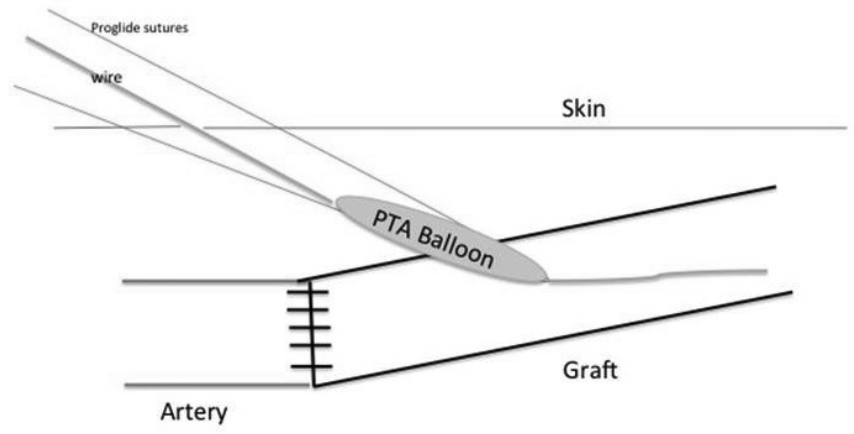

Legend: The angioplasty balloon is inflated whilst half in, half out of the graft, before the large sheath is inserted.

Figure 1: cartoon illustrating predilation with 6 or $8 \mathrm{~mm}$ PTA balloon following preclosing with ProGLide in synthetic vascular graft 


\title{
Mid-aortic syndrome: a rare cause of arterial hypertension in young adults
}

\section{R. Stieger, M. Husmann, P. Suter, T. Pfammatter, B. Amann-Vesti, C. Thalhammer (Zürich)}

Objective: Mid-aortic syndrome (MAS) is characterized by segmental narrowing of the proximal abdominal aorta and may cause ostial stenosis of its major branches, especially the renal arteries.

Methods: We present a case of a young woman with therapy resistant arterial hypertension due to MAS.

Results: A 22-year old asymptomatic woman (BMI 26.9) presented with a therapy resistant hypertension (HT), first recognized at the age of 11 years. Despite different antihypertensive medications blood pressure (BP) remained over $180 / 100 \mathrm{mmHg}$, a $24 \mathrm{~h}-\mathrm{ABPM}$ showed a mean BP of $164 / 119 \mathrm{mmHg}$ with peaks up to $198 / 138 \mathrm{mmHg}$ ). A MR-angiography six month before referral excluded a renal artery stenosis and renal function was normal. Colour coded duplex ultrasound documented a high grade stenosis of the supramesenteric aorta with a peak systolic velocity over 400 $\mathrm{cm} / \mathrm{s}$ and end-diastolic velocity about $180 \mathrm{~cm} / \mathrm{s}$, post-stenotic turbulences, and severe pathologic intrarenal flow with a resistive-index of 0.3. A MR-angiography of the thoracic and abdominal aorta confirmed the high grade stenosis of the supramesenteric aorta. After interdisciplinary discussion at the vascular board an interventional therapy with PTA and stent implantation (Palmaz 4014 on $10 \mathrm{~mm}$ balloon) was performed without complications. After successful intervention the patient felt dizzy with a BP of 116/64 mmHg, after demission BP was around 140/90 mmHg in everyday life without any antihypertensive drugs.

Conclusion: The cause of the resistant HT in this young woman was a severe reduction of the renal perfusion due to a supramesenteric stenosis of the aorta. The mid-aortic syndrome represents a potentially curable hypoplasia of the aorta with potentially reduction of the perfusion of visceral and renal arteries. Renovascular hypertension is the most significant complication of MAS, whose exact etiology is still unknown. Up to date only about 250 cases were described in the literature and a congenital pathology is suspected as well as a possible genetic component.

\section{P11}

Endovascular treatment of aorto-venous fistulas

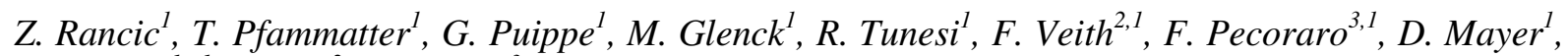 \\ M. Lachat ${ }^{1}\left({ }^{1}\right.$ Zürich, ${ }^{2}$ New York, ${ }^{3}$ Palermo)
}

Objective: Primary aorto-venous fistula (AoVF) is rare complication of ruptured abdominal aortic aneurysm (AAA). The reported mortality for surgical treatment ranges between 16 and 66\%. Endovascular repair of infrarenal AoVF is feasible, efficient and safe procedure, with reduced risk of massive bleeding. The aim of the study is to present our experience in endovascular treatment of AoVF.

Methods: Retrospective database review of all patients with ruptured AAA identified three patients treated at out institution for AoVF caused by spontaneous AAA rupture during the 10 years 20042013. In two patients the aneurysm was infrarenal, and in one juxtarenal.

Results: We report three patients who experienced rupture of AAA in retroaortic left renal vein (two patients) and inferior vena cava (one patient). In two patients diagnosis was made at admission in shock room by computed tomography angiography (CTA). In one patient, who required in other hospital emergency operation because of perforation o acute sigmoid diverticulitis, diagnosis of AoVF was made during the operation. The intubated patient was referred to our hospital where CTA 
confirmed diagnosis. In all but intubated patient procedure was performed in local anesthesia with moderate analgosedation using a percutaneous access to both common femoral arteries. In all patients modular bifurcated stent graft was deployed, in two with transrenal, and in one with infrarenal fixation. In one patient adequate proximal landing zone necessitated covering of left renal artery that was remained patent using a chimney graft. No one stent/ stent graft was placed within the inferior vena cava. Immediate technical success was $100 \%$, with all procedures completed as planned. There was no 30-day mortality and morbidity. Impaired renal function recovered within two months in all patients; no one patient required permanent or temporary dialysis. During the mean follow up of 36 months (range 24-49 months) aneurysm sac either did not change (one patient) or showed decrease in diameter (two patients). In all patients the fistula channel was completely occluded.

Conclusion: Endovascular treatment is effective option for treatment of patients with ruptured AAA and AoVF. Adjunctive endovascular techniques (chimney, and parallel grafts) may extend the use of stent-grafts to patients with juxtarenal aortic -, and common iliac artery aneurysms.

\section{P18}

\section{Can carotid surgery prevent patients from suicide?}

\section{R. Wenger, J. Duwe, D. Lazzarini Baur, R. Seelos, S. Ockert (Luzern)}

Objective: The association of depression with cerebrovascular disease has been recognized by clinicians for almost 100 years. Nowadays depression and even an increased risk of suicide after stroke are well known. But there are no data about acute suicidal tendency after embolic cerebrovascular disease. We present a case report of suicide attempt associated with carotid embolic events.

Methods: Admission took place of a 53-year-old after trying to commit suicide by cutting both wrists. Beside the radial lesions the patient additionally suffered of acute heavy pain of his right lower leg. The examination showed signs for an acute occlusion of the right femoral artery. Simultaneously to the emergency-surgery on the wrists a femoral-thrombectomy was performed. The patient was known to suffer of short-term depression treated under outpatient condition without signs for acute suicidal tendency. Searching the source of the embolic event an electrocardiographic monitoring showed no evidence of irregularities and a duplex sonography of the aorta showed no aneurysm. During the postoperative course the patient occasionally behaved inadequate and agitated. An MRI of the head and neck initiated by the clinical psychiatrist showed multiple infarcts at the left side of the brain and some irregularity on the left carotid bifurcation. A duplex sonography detected a fresh floating thrombus formation in the left internal carotid artery.

Results: A left sided thrombectomy with local carotid-endarterectomy in a local anaesthesia setting was performed immediately. No postoperative complications occurred. The patient recovered well without any psychiatric disorder and absence of depression signs and was discharged into rehabilitation with oral anticoagulant therapy.

Conclusion: Numerous emotional and behavioural disorders occur following cerebrovascular lesions. The most common of these is depression with a frequency of 18-60\%. Other post stroke emotional or behavioural disorders include mania, bipolar-, anxiety disorder, apathy, and pathological crying. In awareness of these facts and the clinical presentation of the patient, inadequate behaviour combined with an embolic event of unknown origin we have been able to detect a carotidal based cerebrovascular disease and maybe saved the patient from a bigger cerebral infarct. As a result we would summarize that carotid surgery has the potency to cure psychiatric disorders in special cases. 